\title{
Cyclically parthenogenetic rotifers and the theories of population and evolutionary ecology
}

\author{
Manuel Serra, Eduardo M. García-Roger, Raquel Ortells and María José Carmona* \\ Cavanilles Institute of Biodiversity and Evolutionary Biology, University of Valencia (Spain). \\ * Corresponding author: carmona@uv.es
}

Received: 15/02/18 Accepted: 24/09/18

\begin{abstract}
Cyclically parthenogenetic rotifers and the theories of population and evolutionary ecology
\end{abstract}

Cyclically parthenogenetic rotifers are facultative sexual aquatic microinvertebrates that live in continental and coastal waters and attracted the scientific interest of Professor M. R. Miracle. Some of her early studies anticipated the use of these rotifers as model organisms to test hypotheses in population and evolutionary ecology. This short review is aimed to stress the research she initiated at the University of Valencia. With this aim in mind, we enumerate and comment on (1) the biological and ecological features of rotifers that make them remarkable model organisms and (2) the research fields influenced by rotifer population biology. Among the latter, we selected some topics in order to illustrate how rotifer studies have contributed to our knowledge: phenotypic plasticity, competition and coexistence among cryptic species, the evolution of sex and complex life cycles, and aging. We deeply review studies on rotifer ecological genetics and evolutionary ecology with an emphasis on population studies conducted in eastern Spain and fostered by Professor Miracle. We conclude that rotifer populations harbor high local genetic diversity, with the occurrence of clonal selection during the planktonic growing season. Moreover, studies show that they have high population differentiation, which holds signatures of historical events (e.g., glacial refugia and posterior range expansion). Additionally, differential local adaptation occurs even among neighboring populations. Two remarkable conclusions are that (1) population differentiation in rotifers is most likely due to persistent founder effects rather than to "isolation by adaptation" and (2) rotifer populations can differentially adapt to the levels of environmental uncertainty in their respective localities. This occurs by adjusting the timing of sex and initiating sex and diapausing egg production earlier when populations inhabit localities with higher uncertainty. Related to environmental uncertainty but also to other environmental features (novel environments where recombination is needed to fuel natural selection, nutrient availability, etc.), experimental evolution studies have found that laboratory populations evolve quickly, allowing them to become easily adapted to new conditions. We suggest that rotifers should be used in the close future to address additional central hypotheses in evolutionary ecology as a result of the feasibility of experimental evolution and resurrection ecology on one hand and "omics" tools on the other hand. As specific topics for future research, we highlight the evolution of sex, speciation, eco-evolutionary dynamics and the regulation of complex life cycles in relation to environmental cues.

Key words: cyclical parthenogenesis, zooplankton, population differentiation, local adaptation, cryptic species, competitor coexistence, sexual reproduction, M.R. Miracle

\section{RESUMEN}

Los rotíferos partenogenéticos cíclicos y las teorías de ecología de poblaciones y evolutiva

Los rotíferos partenogenéticos cíclicos son microinvertebrados acuáticos sexuales facultativos de aguas continentales y costeras, que despertaron el interés cientifico de la profesora M. R. Miracle. Algunos de sus primeros estudios anticiparon el uso de estos rotiferos como organismos modelo para comprobar hipótesis en ecología de poblaciones y evolutiva. En esta breve revisión pretendemos destacar las investigaciones que inició en la Universitat de València. Así, enumeramos y comentamos (1) las características biológicas y ecológicas de los rotiferos que los convierten en organismos modelo, y (2) los campos de investigación impulsados por la biología de poblaciones de rotíferos. Entre estos últimos, hemos seleccionado la plasticidad fenotípica, las especies crípticas y la coexistencia de competidores, la evolución del sexo y los ciclos de vida complejos, y el 
envejecimiento, para mostrar cómo los estudios de rotíferos han contribuido al conocimiento. A continuación, revisamos más detalladamente los estudios sobre genética ecológica y ecología evolutiva en rotíferos, destacando las contribuciones en estudios realizados en España oriental, los cuales fueron incentivados por la profesora Miracle. Concluimos que en las poblaciones de rotiferos existe una gran diversidad genética local, y se produce selección clonal durante el periodo de crecimiento planctónico. Además, los estudios muestran la alta diferenciación interpoblacional, que mantiene la huella de eventos históricos (por ejemplo, la existencia de refugios glaciales y de expansiones de rango posteriores). Además, la adaptación local diferencial ocurre incluso entre poblaciones vecinas. Dos conclusiones notables son: (1) la diferenciación poblacional en rotiferos se debe probablemente a los efectos persistentes del fundador, más que al “aislamiento por adaptación”, y (2) las poblaciones de rotiferos pueden adaptarse diferencialmente a los niveles de incertidumbre ambiental de sus localidades. Esto último ocurre mediante un ajuste del momento de la reproducción sexual, iniciando la producción de huevos de diapausa de forma más temprana en las poblaciones de localidades con mayor incertidumbre ambiental. En relación con la incertidumbre ambiental, pero también con otras características ambientales (ambientes nuevos donde la recombinación es necesaria para que se produzca la selección natural, disponibilidad de nutrientes...), los estudios de evolución experimental han encontrado que las poblaciones de laboratorio evolucionan rápidamente para adaptarse a las nuevas condiciones. Como prospectiva, sugerimos que, en un futuro cercano, con los rotíferos se abordarán hipótesis adicionales de ecología evolutiva, por un lado, como resultado de la viabilidad de la evolución experimental y de la ecología de la resurrección y, por el otro, por el desarrollo de las herramientas “ómicas". Para terminar, proponemos temas específicos para futuras investigaciones: evolución del sexo, especiación, dinámicas eco-evolutivas, y regulación de ciclos vitales complejos en relación con señales ambientales.

Palabras clave: partenogénesis cíclica, zooplancton, diferenciación poblacional, adaptación local, especies crípticas, coexistencia entre competidores, reproducción sexual, M.R. Miracle

\section{Preface}

Among the numerous papers authored by Professor María Rosa Miracle, two of them — published in the first period of her scientific life - can now be regarded as anticipatory clues for the role that rotifers would play in developing and testing theories in evolutionary and population ecology. In the first, Miracle (1974) used rotifer population densities recorded after a sampling campaign in Banyoles Lake for her $\mathrm{Ph}$. D. thesis. Using this database, she applied a principal component analysis in an approach in which one can feel the signature of her major professor, Ramón Margalef. As a result, Prof. Miracle was able to identify niche partitioning in an assemblage of rather similar species (congeneric rotifers) dwelling in a rather spatially homogeneous environment (the planktonic environment). Not surprisingly, this work attracted the attention of George E. Hutchinson, the great limnologist who chaired the American Society of Naturalists (i.e., an association devoted to the study of evolution; Hutchinson, 1959). Regarding Prof. Miracle's approach, Hutchinson (1979) wrote, "This mode of proceeding is perhaps the purest type of niche analysis available". The second of the papers was coauthored by Charles E. King (King \& Miracle, 1980) after a short stay by Prof. Miracle at Oregon State University and was first presented at the second International Rotifer Symposium. Miracle contributed to establishing these symposia by following the initiative of Agnes Ruttner-Kolisko from the very beginning, thus fueling rotifer research and networking around it. King \& Miracle (1980) helped to create a paradigm in rotifer research. Accordingly, genetic population analysis, frequently using molecular markers, was applied to populations and combined with life-table experiments in order to obtain insight into the ecological interpretation of naturally occurring genetic variation. This paradigm is still at work. Among others, these two papers contributed to establishing rotifers as model organisms in hypothesis-driven research in both population and evolutionary ecology. In relation to the latter scientific field, these papers helped to show that small aquatic animals could be used in a field traditionally dominated by the study of large, terrestrial organisms (Rodríguez, 2016). Not less important, Prof. Miracle brought these seminal ideas to the University of Valencia (Spain) and fostered a group of students strongly committed to developing them. Prof. Miracle combined this approach with extensive field studies. As a member of a limnology team led by R. Margalef during 1980-81, she participated in a sampling campaign of coastal ponds and lagoons. The 
resulting data would provide a crucial base for the study of rotifer populations in eastern Spain. Limnology practiced by the school of ecologists founded by R. Margalef gives the most importance to physical-chemical factors. Not surprisingly, Prof. Miracle realized the role of salinity and temperature in rotifer species distributions (Miracle et al., 1987) and life history traits (Miracle \& Serra, 1989). These results are still inspiring current research in studies of the Brachionus plicatilis species complex (Montero-Pau \& Serra, 2011; Gabaldón et al., 2013, 2015, 2017).

\section{INTRODUCTION}

Rotifers (i.e., wheel bearers) are microscopic, aquatic invertebrates that mostly inhabit lakes, ponds, streams and coastal marine habitats. More than 2000 species have been named in the phylum Rotifera, and these have been grouped into three major clades, which are regarded as classes among many taxonomists (Bdelloidea, Monogononta, and Seisonidea). Seisonids (only four species) are obligatory sexuals; bdelloids ( $>360$ taxonomic species) are animals with a worm-like body and obligatory asexuality; monogononts (> 1600 named species) are facultative sexuals. It has been proposed that rotifers cannot be a monophyletic clade and that Bdelloidea and Monogononta are closer to Acanthocephala than to Seisonidea (Mark Welch, 2000; Sielaff et al., 2016). Fontaneto \& De Smet (2015) and Wallace et al. (2015) provide excellent updated information on the biology and general ecology of rotifers.

Population ecology and evolutionary ecology are two closely related fields, and they have been strongly linked with population and quantitative genetics since their very early development, when a trend to unify these fields into a single research programme (sensu Lakatos, 1970) was a common theme (McIntosh, 1985). The development of these fields has been driven by theory, i.e., models (e.g., the logistic model), principles (e.g., competitive exclusion), concepts (e.g., the niche concept), and laws or rules (e.g., Bergman's rule). Concomitantly, this approach uses analysis based on the "isolation of problems" (methodological reductionism) as well as simplifying assumptions, which has been problematic to naturalists and ecologists who address the complexity of natural phenomena. To some extent, this criticism misses the important point of the role of simplification in theoretical develop- ment. For instance, no biologist expects the exponential growth model to describe the dynamics of a population over an extended period, just as no physicist expects the real movement of an object to be described only by the inertia principle (see, Turchin, 2001, for an elaboration of this analogy), which does not diminish the role of simple models in organizing scientific thought and promoting progress (e.g., the logistic model allowed the development of the $r-K$ strategies scheme). Nevertheless, criticism stands. A long time ago, Park (1946) stated that "modern" studies on population ecology include natural populations, laboratory populations and "theoretical populations". Regardless of this assertion, important empirical gaps still exist. Good-quality, descriptive empirical studies on natural populations are abundant and have inspired theoretical ecologists. In contrast, empirical tests of explanatory hypotheses derived from theory have been much delayed. Two obvious factors contributing to this delay are the cost and practical constraints involved in laboratory and field studies, in which confounding factors must be controlled in order to test specific hypotheses. These shortcomings may be partially overcome by using model organisms. Model organisms focus research efforts and thus allow information on their biology to be accumulated. As a result, important synergisms in our knowledge arise. Obviously, there is a trade-off here, as a handful of model organisms are not sufficient to account for the diversity of life. We need a number of cases that range in body size, typical population size, organizational complexity, trophic level, life cycle, etc.

In this short review, we aim to show the realization and the potential of cyclically parthenogenetic rotifers (i.e., rotifers in which sexual and asexual reproduction are facultative) as model organisms to improve our understanding of popu- 
lation dynamics, population structure, and some crucial evolutionary processes, namely, population differentiation (including phylogeography), adaptation and speciation. With this aim in mind, admittedly, the present review is not exhaustive but will stress points that have not been stressed in other recently published reviews on rotifers as model organisms in population and evolutionary studies (e.g., Fussmann, 2011; Snell, 2014; Declerck \& Papakostas, 2017; Stelzer, 2017). We (1) focus on the general topics in which rotifer research has made a significant contribution and show the methodological advantages of the use of rotifers, particularly if the effort is concentrated on a few species and ecosystems. To a large extent, (2) this review is mainly based on studies in which we - the authors - were involved. This is our way of showing the effects of the approach that Prof. Miracle brought to the University of Valencia. Additionally, (3) we will highlight a perspective on the studies on cyclically parthenogenetic rotifers as a continuation of the observed tendencies.

\section{CYCLICALLY PARTHENOGENETIC ROTIFERS: FEATURES AND ASSOCIAT- ED METHODOLOGICAL ADVANTAGES}

Rotifers are among the smallest and most short-lived and quickly reproducing metazoans. Their body size ranges from 40 to $3000 \mu \mathrm{m}$, although most rotifers measure from 100 to 500 $\mu \mathrm{m}$ (Hickman et al., 1997). This microscopic size permits the maintenance of large laboratory populations in small volumes, while the size is large enough to allow the easy observation, manipulation and measurement of individuals (Table 1). As stated by Miracle \& Serra in their review in 1989 , the lifespan of cyclically parthenogenetic rotifers is typically 3-20 days (see also Nogrady et al., 1993), and the lifetime reproductive output of asexual females can reach approximately 20 daughters (King \& Miracle, 1980; Halbach, 1970; Walz, 1987; Carmona \& Serra, 1991; Gabaldón \& Carmona, 2015). Unlike other zooplankters that produce clutches of more than one offspring (e.g., cladocerans and copepods), these rotifers produce offspring sequentially (birth-flow populations; Stelzer, 2005). This has been interpreted as a constraint imposed by the large offspring size relative to the female body mass (14-70\%; e.g., Walz, 1983; Stelzer, 2011a). However, rotifers have the highest intrinsic rates of population growth among multicellular animals (Bennett \& Boraas, 1989), mostly due to their short generation times. For instance, Brachionus plicatilis matures at the age of 24 hours (Temprano et al., 1994) at $25^{\circ} \mathrm{C}$ and $12 \mathrm{~g} / \mathrm{L}$ salinity and has generation times of approximately 3 days. This results in an intrinsic rate of population growth as high as 0.6 days $^{-1}$ (Miracle \& Serra, 1989; Carmona \& Serra, 1991), which is equivalent to doubling the population density every 1.2 days. Their rapid growth and short generation times make rotifers ideal organisms to study rapid trait evolutionary responses (Fussmann, 2011; Declerck \& Papakostas, 2017; Tarazona et al., 2017) and to obtain comprehensive time series of data over many generations within a short experimental time (e.g., Serra et al., 2001).

Most cyclically parthenogenetic rotifers are planktonic filter feeders and may be described as euryphagous, typically feeding on bacteria, algae, protozoa, and yeast, as well as organic detritus (Wallace et al., 2015). Although the species found in different environments often differ in their tolerance to ecological factors, their opportunism and wide ecological adaptability allow a number of species to be easily cultured and maintained - using simple and inexpensive diets - in controlled laboratory environments, including automated intensive continuous-culture systems (chemostats; Walz, 1993). So far, these rotifers are the only aquatic metazoans that have been found to be able to grow under steady-state conditions in semi-continuous and continuous cultures. As a result, they have become proven models for investigating population dynamics (e.g., Booras \& Bennett, 1988; Rothhaupt, 1990; Ciros-Pérez et al., 2001; Fussmann et al., 2003; Gabaldón et al., 2015) and addressing experimental evolution (e.g., Fussmann, 2011; Declerck et al., 2015; Declerck \& Papakostas, 2017; Tarazona et al., 2017). It is worth noting that a substantial portion of the physiological and demographic information allowing the recognition of this status of rotifers came from applied studies. It is a consequence of using rotifers in aquaculture as living 
Table 1. Features of cyclically parthenogenetic rotifers that make them suitable model organisms for studies on population and evolutionary ecology in metazoans. Características de los rotíferos partenogenéticos cíclicos que los convierten en organismos modelo adecuados para estudios de ecología poblacional y evolutiva en metazoos.

Trait (typical or general)

Small size

Sufficiently large size

High growth rate and short generation time

Generalist filter feeders

Ecological adaptability

Eutely

Complex life cycle

\section{Methodological advantage}

Maintenance of large populations in small

volumes under lab conditions.

Ease of handling, allowing individual

measurement and manipulation.

(1) Rapid evolutionary responses; (2) Ease of obtaining data over many generations; (3)

Reasonable experimental times.
Field of study (examples)
Laboratory studies on

population and

evolutionary ecology.

Laboratory studies;

Biometrics;

Demography.

Micro-evolutionary

studies; Experimental

evolution; Local

adaptation; Eco-

evolutionary dynamics.

Laboratory studies on population and evolutionary ecology.

Laboratory studies on population and evolutionary ecology.

Physiological development and the evolution of aging.

Ecology and evolution of sex; Life-history evolution; Trade-offs. 
Table 1. (cont.)

Clonal proliferation

Environmental sex induction

Haploid males

Production of diapausing eggs
(1) Breeding large cohorts of genetically

identical animals; (2) Maintenance of individual genotypes for many generations in the lab; (3)

Replication of genotypes in experiments; (4)

Control of genetic variation in experiments.

Control of sexual reproduction under

experimental conditions.

Development of inbred lines in the laboratory.

(1) Long-term maintenance of stocks; (2)

Assessment of natural population genetic

diversity through the sampling of diapausing egg

banks; (3) Ease of clonal lineage foundation; (4)

Reconstruction of evolutionary trajectories of

natural populations through time via the

"resurrection" of genotypes.
Gene-environment

interactions;

Heritability; Phenotypic

plasticity; Epigenetics.

Ecology and evolution

of sex.

Population inbreeding

and outbreeding.

Laboratory studies;

Ecological and genetic

studies; "Resurrection

ecology"; Dynamics and

evolution of diapause

and related bet-hedging

strategies. food for fish and crustacean larvae (Lubzens et al., 1989, 2001; Hawigara et al., 2007; Kostopoulou et al., 2012) and in ecotoxicological tests (e.g., Snell \& Carmona, 1995; Snell \& Joaquim-Justo, 2007; Dahms et al., 2011).

Rotifer development is direct —without a larval stage - and eutelic (no cell division occurs in the postembryonic period). Rotifers consist of approximately 1000 somatic nuclei, and their oocyte number is fixed at birth (e.g., Gilbert, 1983; Clement \& Wurdak, 1991). Despite being composed of only a few cells, rotifers present remarkable anatomic complexity and have specialized organ systems, including digestive, reproductive, nervous, and osmoregulatory systems. Their eutely - in addition to their short lifespan, rapid growth and ease of culturingmakes them excellent research animals for studies on aging because the tissue cells are not renewed, allowing the investigation of specific theories of senescence (e.g., Carmona et al., 1989; Enesco, 1993; McDonald, 2013; Snell, 2014).

Several of the characteristics that make cyclically parthenogenetic rotifers valuable in population and evolutionary ecological studies pertain to their complex life cycle (Box 1, Fig. 1), which includes multiple generations (Moran, 1994). They are capable of both clonal proliferation through parthenogenesis and sexual reproduction. Clonal reproduction is a unique and powerful experimental tool because high numbers of isogenic individuals (naturally produced clonal lines) can be obtained and maintained for prolonged periods. This allows for replication and comparisons of (1) various environments against a defined genetic background or (2) various genotypes against a defined environment. 


\section{BOX 1. Cyclical parthenogenesis in rotifers.}

Populations of cyclically parthenogenetic rotifers are typically temporal in the plankton and recolonize the water column during the planktonic growth cycle through the hatching of diapausing eggs from pond and lake sediments (Fig. 1). The hatchlings are asexual (i.e., amictic) females that produce diploid, subitaneous eggs that - barring mutations - develop into genetically identically asexual females (clonal proliferation). The sexual phase begins with the parthenogenetic production of sexual (i.e., mictic) daughters by asexual mothers as a fraction of their offspring in response to environmental inducing factors. Sexual females produce meiotic haploid eggs that develop parthenogenetically into haploid males, and if young sexual females mate, their haploid eggs are fertilized and develop into diapausing eggs (actually cysts). These eggs can survive adverse conditions and enable populations to recolonize the water column when suitable conditions resume at the site and also disperse to other habitats. After receiving appropriate stimuli, a fraction of the diapausing egg hatch into asexual females, and a new growing season begins. The unhatched fraction of diapausing eggs accumulate in the sediment, forming banks.

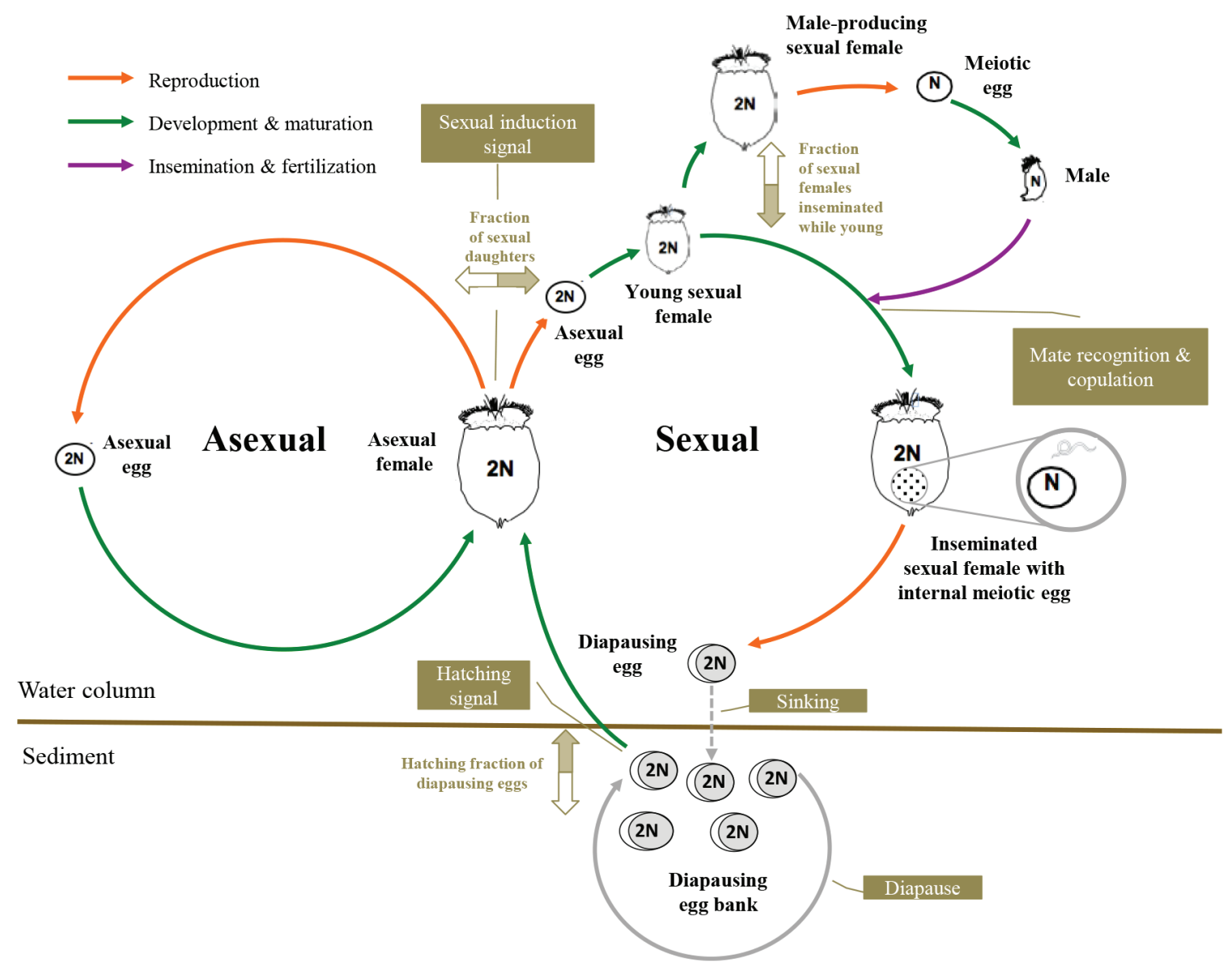

Figure 1. Life cycle of monogonont rotifers (modified from Serra et al., 2018). Ciclo vital de rotiferos monogonontes (modificado a partir de Serra et al., 2018). 
This facilitates genetic and environmental influences on the phenotype to be conveniently separated in experimental settings, which allows evolutionary ecology questions that are otherwise difficult to approach (e.g., phenotypic plasticity, the genomic basis of ecologically relevant traits, changes in gene expression in response to environmental conditions, and epigenetic phenomena) to be addressed.

In cyclically parthenogenetic rotifers, sexual reproduction is dependent on environmental factors that may differ among genera or species, such as the photoperiod, population density, and diet (e.g., Gilbert, 1974; Pourriot \& Snell, 1983; Schröder, 2005). Therefore, for instance, the population density - which acts as an inducing cue in the genus Brachionus - can be used in the laboratory to experimentally manipulate sex initiation, as studied by Prof. Miracle and coworkers (Carmona et al., 1993, 1994; see also Stelzer \& Snell, 2003). This is useful in studies examining relevant aspects of the ecology of sexual reproduction (see next section). During sexual reproduction, asexual females produce parthenogenetically sexual females as some fraction of their offspring. That is, asexual reproduction does not stop, and the two reproductive modes co-occur in the population. Thus, the level of sexual reproduction (i.e., the fraction of sexual females) can be correlated with environmental factors and habitat characteristics to analyze the optimization of investment into sexual reproduction (Serra et al., 2004). While in cladocerans - the other group of cyclical parthenogenetic zooplankters - the same female can produce meiotic and ameiotic eggs, in rotifers, these two types of eggs are produced by different females. Only the oocytes of so-called sexual (or mictic) females undergo meiosis, and they develop into haploid males (if not fertilized) or diploid diapausing eggs (if fertilized). Therefore, the sex-determination system in rotifers is haplodiploid, and because each male represents a random haploid sample of its mother genome, mating between males and sexual females of the same clone is genetically equivalent to selfing. This allows for the easy development of inbred lines and the study of inbreeding depression effects (Birky, 1967; Tortajada et al., 2009), although controlled reproductive crosses are very laborious to undertake. Another feature of cyclically parthenogenetic rotifers that makes them useful for examining the evolutionary maintenance of sex (e.g., investment into sexual reproduction and the cost of sex) is that sexual and asexual females are virtually identical in morphology and, if belonging to the same clone, have the same genetic background. This facilitates the comparison of the life-history traits of females differing only in their reproductive mode (e.g., Carmona \& Serra, 1991; Gilbert, 2003; Snell, 2014; Gabaldón \& Carmona, 2015) or in the proportion of sexual daughters produced (e.g., Carmona et al., 1994; Fussmann et al., 2007) without the interference of other phenotypic variation (King, 1970). Given the morphological similarity between asexual and sexual females, they have to be identified based on their eggs. Thus, a caveat is that neonate and non-ovigerous females cannot be classified, resulting in a smaller practical sample size for the calculation of the level of sexual reproduction.

An additional feature distinctive of cyclically parthenogenetic rotifers associated with their life cycle is that the development of sexually produced eggs is halted temporarily during a resting stage -i.e., sex and diapause are linked (Schröder, 2005). The arrested embryos can survive adverse conditions and remain viable for decades, providing dispersal in both space and time (Kotani et al., 2001; García-Roger et al., 2006a). Not all diapausing eggs hatch when favorable conditions occur; instead, some of them remain viable in the sediment for longer periods, forming egg banks (Evans \& Dennehy, 2005). In terms of methodological advantages, diapausing rotifer eggs provide (1) the long-term maintenance of culture stocks, (2) the rapid and cost-effective assessment of the genetic diversity of natural populations through the sampling of diapausing egg banks instead of sampling rotifers from the water column, (3) the easy establishment of clonal lines in the laboratory, and (4) the investigation of past rotifer populations in the field. Regarding the last point (i.e., resurrection ecology; Brendonck \& De Meester, 2003), the possibility of measuring evolutionary change by comparing past populations to current ones is made 
feasible by sampling diapausing egg banks in lake or pond sediments, which also include a record of environmental changes (Hairston et al., 1999; Piscia et al., 2016; Zweerus et al., 2017).

Working with rotifers poses challenges in addition to those already mentioned. First, rotifer cultures are not free from crashes and contamination (e.g., by ciliates). These are problems that are not exclusive to rotifers but shared with all other experimental organisms. Luckily, the opportunity to use continuous-culture techniques (e.g., chemostats) for rotifers is helping cultures to be maintained for extended periods without contamination (see Declerck \& Papakostas, 2017). In addition to that challenge, it is also worth mentioning that complete genome data for monogonont rotifers are still very limited, with the only exception of Brachionus calyciflorus and $B$. plicatilis, for which genome assembly information is recently available (Kim et al., 2018; Franch-Gras et al., 2018).. However, genomic tools are increasingly affordable for research groups, and other partial-genome approaches have been successfully implemented in rotifers (e.g., Mark Welch \& Mark Welch, 2005; Denekamp et al., 2009; Montero-Pau \& Gómez, 2011; Hanson et al., 2013a,b; Ziv et al., 2017).

\section{TESTING HYPOTHESES REGARDING POPULATION AND EVOLUTIONARY ECOLOGY USING ROTIFERS}

The attention to rotifers in ecological and evolutionary studies can be quantitatively illustrated using the number of papers published as a metric. After a search in the Thomson ISI Web of Science for "(ecol* AND evol*) AND (rotifer*)" in the topic search query, we selected papers in the field of evolutionary biology and summed the number of papers in this field from our own archives. This search yielded 706 records for the period 1966-2017. Notably, the counts per year showed an increasing trend, as also occurs for all studies in evolutionary ecology ("ecol*" AND "evol*"; Fig. 2). The topics in which rotifer research has made a significant contribution are summarized in Table 2, with references to the most representative studies. Below, we go over the main findings derived from these studies.

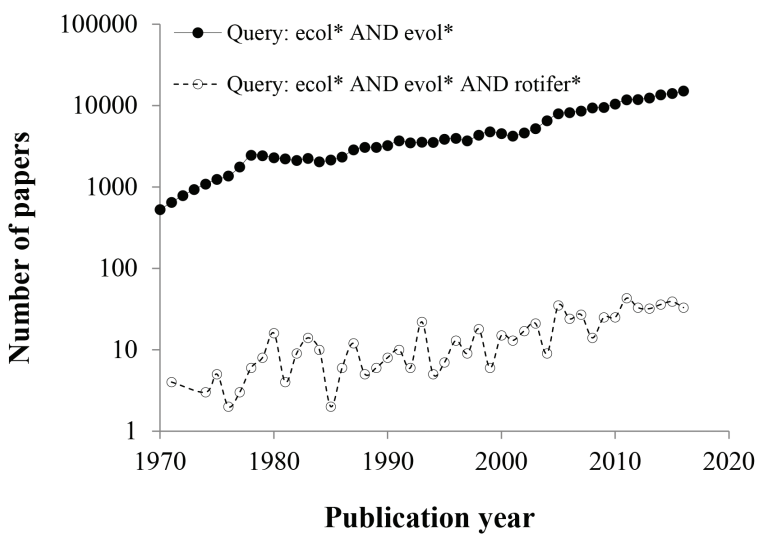

Figure 2. Absolute number of papers on ecology and evolution published every year since 1970 . Depicted are the numbers of papers returned after topic search queries for all taxa (ecol* AND evol*; filled dots) and rotifers only (ecol* AND evol* AND rotifer*; open dots). Counts were obtained from the Thomson ISI Web of Science ${ }^{\circledR}$ after filtering by research domain $=$ science and technology and database $=$ Web of Science Core Collection. Two publications for all taxa published prior to 1970 were omitted. Número absoluto de artículos sobre ecología y evolución publicados anualmente desde 1970. Se muestran los números de artículos resultantes de las consultas de búsqueda por tema para cualquier taxa (ecol * AND evol *; puntos negros) y para rotíferos solamente (ecol * AND evol * AND rotifer *; puntos blancos). Los recuentos se obtuvieron de Thomson ISI Web of Science ${ }^{\circledR}$ después de filtrar por Research domain $=$ Science and technology, $y$ Database $=$ Web of Science Core Collection. Se omitieron dos publicaciones anteriores a 1970 para la búsqueda correspondiente a todos los taxones.

\section{Phenotypic plasticity}

Clonally reproducing organisms, by allowing the control of genetic variation, offer an opportunity to study phenotypic plasticity (i.e., the ability of individual genotypes to produce different phenotypes when exposed to different environmental conditions; see Pigliucci et al., 2006; Fusco \& Minelli, 2010) and to estimate reaction norms. The thermal environment is regarded as crucial in shaping the adaptations and distributions of living beings. Not surprisingly, the developmental morphological response to temperature has been a widely studied form of phenotypic plasticity in rotifers. In many rotifer species, a larger body size is observed at low temperatures, a phenomenon also observed in other ectotherms and known as the temperature-size rule (TSR, Atkinson, 1994). In rotifers, the pioneering work of Prof. 
Miracle provided support for the TSR in $B$. plicatilis (Serra \& Miracle, 1983; see also Snell \& Carrillo, 1984; Walczynska et al., 2017) and more recently in Synchaeta (Stelzer, 2002) and B. calyciflorus (Sun \& Niu, 2012). There is also important phenotypic plasticity in rotifer egg size, which was first noticed by Prof. Miracle and coworkers (Serrano et al., 1989; see also Galindo et al., 1993; Stelzer, 2005; Sun \& Niu, 2012).

Inducible defenses - another type of phenotypic plasticity - are hypothesized to evolve when defenses are costly and predation pressure fluctuates. They have been reported to occur in rotifers, in which their occurrence is triggered by the presence of some reliable cues released by predators (Gilbert, 2009; 2011). As a consequence of the development of inducible defenses, rotifers are expected to experience fitness costs (Gilbert, 2013), although such costs can be manifested in different forms (e.g., decreased reproduction, as observed in B. angularis, or reduced sexual investment, as observed in B. calyciflorus; Yin et al., 2016). Interestingly, selection exists during a season for much of this response when predators are present (Halbach \& Jacobs, 1971; reviewed in Gilbert, 2018) such that developmental and selective environments overlap in their time scales. This shows that evolutionary responses may exist in rotifer populations at a typical ecological scale of observation. Using rotifers, it has been shown that inducible prey defenses enhance plankton community stability and persistence, likely through negative feedback loops that prevent strong population oscillations

Table 2. Examples of studies using rotifers in the development of population and evolutionary ecology hypotheses and theories. Ejemplos de estudios que utilizan rotíferos en el desarrollo de hipótesis y teorías sobre ecología de poblaciones y evolutiva.

Topic

Adaptive phenotypic plasticity

Population differentiation and local adaptation

Niche differentiation

Cryptic speciation

Evolutionary ecology of sex

Evolution of diapause

Aging

Experimental evolution

\section{Examples}

Serra \& Miracle, 1983; Snell \& Carrillo, 1984; Stelzer, 2005;

Walczynska et al., 2017.

Campillo et al., 2009; Alcántara-Rodríguez et al., 2012; Franch-Gras et al., 2017.

Miracle, 1974; Ciros et al., 2004; Gabaldón et al., 2013, Lapesa et al., 2002; 2004.

Gómez \& Serra, 1995; Gómez et al., 2002; Campillo et al., 2005; Walsh et al., 2009; Obertegger et al., 2012; Mills et al. 2017.

Aparici et al., 1998, 2002; Carmona et al. 2009; Becks \& Agrawal, 2010; 2012; Stelzer \& Lehtonen, 2016.

Denekamp et al., 2009, 2011; Martínez-Ruiz \& García-Roger, 2015; Stelzer, 2017.

King \& Miracle, 1980; Carmona et al., 1989. Carmona \& Serra, 1991; Snell et al., 2012; Snell, 2014; Snell et al., 2015; Gribble \& Mark Welch, 2017.

Fussmann et al., 2003; Smith \& Snell, 2012; Declerck et al., 2015; Tarazona et al., 2017. 
(Van der Stap et al., 2007; Aránguiz-Acuña et al., 2010). These results provide support for the idea that evolutionary changes in these organisms may have consequences for the functioning of entire ecosystems (Matthews et al., 2014).

Although morphology is the most studied feature, phenotypic plasticity also refers to changes in an organism's behavior and/or physiology (for a review, see Gilbert, 2017). A striking example in rotifers is the transition from the production of exclusively asexual daughters to the production of sexual and asexual daughters (see above). Because phenotypic plasticity is the result of shifts in gene expression, one powerful way to examine how rotifer genotypes respond to particular environments is to use transcriptomics, which is currently easily applicable to many ecological model systems, with rotifers not being an exception (Denekamp et al., 2009; 2011; Hanson et al., 2013a).

Because rotifers can show (1) remarkable phenotypic plasticity, (2) within-species genetic variation -which may involve ecologically relevant traits (e.g., Campillo et al., 2009; Franch-Grass et al., 2017a, see below) - and (3) cryptic speciation resulting in complexes of reproductively isolated groups with very similar morphology (see below), special care is needed in order to reliably dissect these levels of variation. Otherwise, the inaccurate identification of these phenomena may misguide the evolutionary and ecological explanations that are hypothesized. Interestingly, the association between small rotifer size and high temperature can be discomposed into differential species adaptation, within-species evolution, and co-gradient variation due to phenotypic plasticity (Walczynska \& Serra, 2014a,b; Walczynska et al., 2017).

\section{Aging, at the crossroads between physiology and evolution}

Complex physiological changes are involved in aging, but from a life history perspective, the result is a decrease in fitness components (i.e., survival and fecundity) with age after maturity. This poses the question of why natural selection does not act to prevent aging but most likely has selected for it. The evolutionary theory of aging is based on the notion that the strength of natural selection declines with progressive age (Rose, 1991), being widely acknowledged that high performance at a young age occurs at the cost of poor performance at an older age. Rotifers have been shown to be particularly useful in studies focused on the physiological side of the problem (for recent reviews, see Snell, 2014; Snell et al., 2015). Many of the abovementioned features of monogonont rotifers, particularly eutely, their ease of culturing and their short generation times, have allowed these organisms to be considered adequate experimental organisms for the study of aging (Enesco, 1993). The most successful results of aging studies in rotifers include evidence of lifespan extension through caloric restriction (Gribble et al., 2014; Snell, 2015), the supplementation of antioxidants in the diet (Snell et al., 2012) or the effect of controlled environmental conditions (e.g., low temperatures; Johnston \& Snell, 2016). Another advantage of rotifers in the study of aging relies on the availability of ready-for-use genomic tools that can be applied to rotifers (Gribble \& Mark Welch, 2017). These new tools have allowed the discovery of genes involved in aging by comparing gene expression in individuals of different ages (Gribble \& Mark Welch, 2017) as well as the identification of target genes whose expression can be altered at will by novel techniques, such as RNAi knockdown (Snell et al., 2014).

\section{Studies on the evolution of sex and life cycle traits}

One of the major problems still unsolved in evolutionary biology is determining which evolutionary forces maintain sex in populations, that is, which advantages compensate for the costs of sex (Williams, 1975; Maynard Smith, 1978; Bell, 1982). Sex has inherent costs (for a review, see Stelzer, 2015) and potential advantages due to recombination (e.g., Hurst \& Peck, 1996; Roze, 2012). A recurrent problem when relating sexual reproduction to environmental or genetic factors is that, for many organisms, sex follows an all-or-nothing rule. Fortunately, cyclical parthenogens have the advantage of displaying a range of investment in sexual vs. parthenogenetic 
reproduction (Stelzer \& Lehtonen, 2016). Several studies have shown strong selection against sexual investment during the course of a growing season in Brachionus species or in laboratory cultures (Fussmann et al., 2003; Carmona et al., 2009). The direct comparison between obligate asexual and facultative sexual strains of $B$. calyciflorus has shown how the former typically outcompetes the latter (Stelzer, 2011) over the short term. Overall, these studies provide evidence for the costs of sex. Interestingly, recent experiments have shown how environmental heterogeneity could favor sexual reproduction in rotifers (Becks \& Agrawal, 2010, 2012). These authors found that sex evolved at higher rates in experimental populations of $B$. calyciflorus during adaptation to novel environments in comparison to populations in which environmental conditions were kept constant and that the sexual offspring showed higher fitness variability, in agreement with the idea that sex generates new genetic combinations (Becks \& Agrawal, 2012).

Another important question raised by cyclical parthenogenesis is why this cycle is not a more common cycle. Cyclical parthenogenesis is not a monophyletic trait (i.e., it has evolved several times) and has been regarded as the optimal combination of fast asexual proliferation and episodic sex. Theoretical studies predict that a little of sex is enough to fully provide the advantages of recombination while minimizing the costs (Peck \& Waxman, 2000). However, this cycle is found in only approximately 15000 animal species (Hebert, 1987) out of the estimated 7.77 million species of animals on Earth (Mora et al., 2011). A sound explanatory hypothesis is that cyclical parthenogenesis is inherently unstable in evolutionary terms because its transition to obligate asexuality does not require the acquisition of a new function but only the loss of the sexual function. Moreover, when this transition occurs, the newly emerged asexual linages outcompete the cyclically parthenogenetic lineages -which have to pay the short-term costs of sex- before the long-term advantages of sex arrive. In the case of ancient cyclical parthenogens, the linkage between sex and the production of resistant stages has been suggested to be responsible for the maintenance of cyclical parthenogenesis (Simon et al., 2002; Serra et al., 2004). That is, recurrent adverse periods cause short-term selection for diapause, the linkage between diapause and sex causes the maintenance of sex, and this allows the long-term advantages of sex to be realized. Recent theoretical research has shown that the costs of sex decline when sex is linked to diapause (Stelzer \& Lehtonen, 2017), which supports the idea that the short-term advantages of diapause counterbalance the costs of sex and prevent facultative sexuals from being displaced by obligate asexuals.

\section{Hidden biodiversity and local species richness}

A fortunate by-product of molecular marker studies when applied to what was thought to be a single species is unmasking cryptic species (also called sibling species; Gómez et al., 2002a; Walsh et al., 2009; Leasi et al., 2013; Mills et al., 2017), a phenomenon that has led to research on the development of molecular tools for species identification (Gómez et al., 1998; Montero \& Gómez, 2011; Obertegger et al., 2012). Among metazoans, rotifers seem to have one of the highest levels of hidden diversity resulting from cryptic speciation, with at least 42 cryptic species complexes (Fontaneto et al., 2009; Gabaldón et al., 2017). To date, the best-studied cryptic species complex is that of Brachionus plicatilis (Box 2), for which a multifold approach integrating morphological and DNA taxonomy, cross-mating experiments, and ecological and physiological evaluations has been used to separate species and understand their ecological divergence and the conditions favoring their coexistence (e.g., Serra et al., 1998; Ciros-Pérez et al., 2001; Gómez et al., 2002a; Suatoni et al., 2006; Serra \& Fontaneto, 2017; Mills, 2017). Because monogonont rotifers reproduce sexually during part of their life cycle (Box 1), evidence of species status can be provided through pre-mating reproductive isolation. Interestingly, contact chemoreception of a surface glycoprotein serves as a mate recognition pheromone (MRP; Snell et al., 1995). Molecular and genetic studies have identified the protein and gene responsible, making rotifers a premier model for mechanistically investigating population differentiation and 


\section{BOX 2. Cryptic speciation in the monogonont rotifer species complex Brachionus plicatilis.}

Cryptic (also called sibling) species are those having great morphological similarity such that classical, morphologically based taxonomy considers them to be a single species (Knowlton 1993; Bickford et al., 2007). The understanding of the extent of cryptic diversity within any given taxon is essential not only to assess its overall diversity but also to recognize the complexity of its ecological interactions and evolutionary histories. Such knowledge is even more essential when the taxa under consideration are valuable ecological and evolutionary models, as is the case of monogonont rotifers.

The cryptic species complex Brachionus plicatilis is currently the best studied among rotifers. It is known to host a large amount of hidden and still not completely resolved diversity (Mills et al., 2017; Serra \& Fontaneto, 2017). The most recent study performed using several approaches to DNA taxonomy confirmed the existence of 15 previously described species within the complex (Mills et al., 2017; Fig. 3). Several studies have demonstrated prezygotic and postzygotic reproductive isolation among some members of the complex (Ortells et al., 2000; Suatoni et al., 2006; Snell \& Stelzer, 2005). In laboratory populations, some species have only been partially isolated. Only six species have been formally described: B. plicatilis s.s. (Müller, 1786), B. rotundiformis (Tschungunoff, 1921), B. asplanchnoidis (Charin, 1947), B. ibericus (Ciros-Pérez et al., 2001), B. manjavacas (Fontaneto et al., 2007), and B. koreanus (Hwang et al., 2013); the remaining species have received unofficial names (Fig. 3). Morphological discrimination among some species of this complex is possible but complicated (Ciros-Pérez et al., 2001; Campillo et al., 2005; Fontaneto et al., 2007). Despite their great morphological similarity and close phylogenetic relationships —which result in expectable similar ecological requirements (i.e., niche conservatism) and strong competitive interactions - subsets of these species often co-occur in many waterbodies of the Iberian Peninsula (Ortells et al., 2003; Gómez, 2005; Lapesa et al., 2004; Montero-Pau et al., 2011). Information regarding the mechanisms that allow cryptic species coexistence is available for several species of the complex (B. plicatilis, B. ibericus, B. rotundiformis and B. manjavacas) based on studies of their ecological requirements, their seasonal specialization, and the characterization of their abiotic and biotic niche differentiation (Gabaldón et al., 2017).

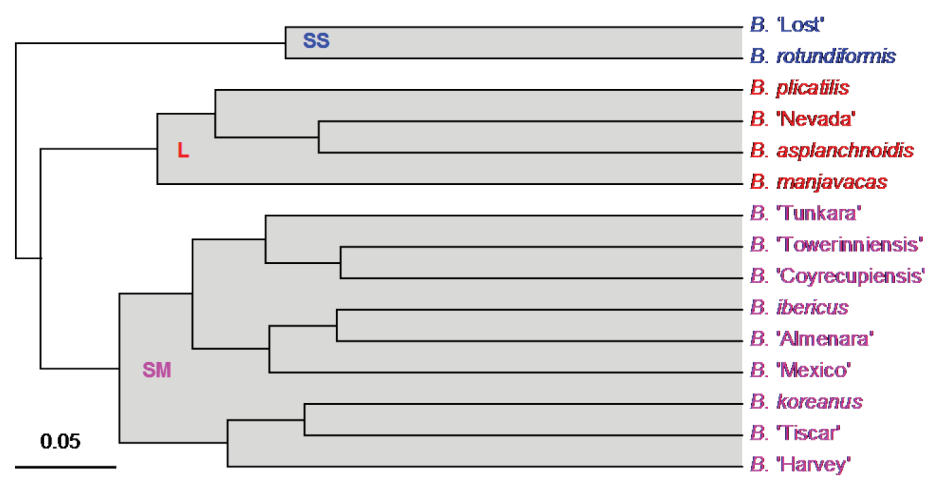

Figure 3. Phylogenetic relationships in the B. plicatilis species complex (modified after Serra \& Fontaneto, 2017; see this publication for details) showing 15 putative species (branching within these species is not shown). Shaded clades indicate the three main groups that correspond with the classical size-based morphological classification (SS: small; SM: small-medium; L: large; see Ciros et al., 2001). Relaciones filogenéticas en el complejo de especies B. plicatilis (modificado a partir de Serra \& Fontaneto, 2017; donde pueden verse más detalles), en las que se muestran 15 especies putativas (sin detalles de las ramificaciones dentro de especie). Los clados sombreados indican tres grupos principales correspondientes con la clasificación morfológica clásica basada en tamaño (SS: pequeño, del inglés "small”; SM: pequeño-mediano, del inglés "small-medium”; L: grande, del inglés "large"; véase Ciros et al., 2001). 
cryptic speciation (Snell et al., 1995, 2009; Snell \& Stelzer, 2005; Gibble \& Mark Welch, 2012).

Uncovering cryptic species is an important taxonomic issue in order to increase the accuracy of global biodiversity estimates. The case of the $B$. plicatilis species complex clearly shows the magnitude of the possible underestimation: what was thought to be a single rotifer species in the 1980 s is currently regarded as a complex of fifteen cryptic species (Mills et al., 2017). There are several important ecological implications of the uncovering of cryptic species (Gabaldón et al., 2017). One is the need to re-evaluate the eurioic character and the cosmopolitan distribution of the erroneously considered single species (Gómez et al., 1997). Another is the need to discriminate between within-species variation (either genetic or due to the developmental environment) and among-species variation; for instance, to know whether apparent cyclomorphosis (i.e., seasonal change in the morphology of a population) may actually be a repeated pattern of seasonal substitution of similar species (Gómez et al., 1995; Ortells et al., 2003). Most importantly, uncovering cryptic species allows the local species richness to be evaluated and calls for explanations for the coexistence of species that are expected to have very similar niches, resulting in strong competition. Rotifer studies have shown that the co-occurrence of cryptic species in a particular location is rather common (Ortells et al., 2000; 2003; Gómez et al., 2005; Lapesa et al., 2004; Montero et al., 2011; Leasi et al., 2013). In the $B$. plicatilis species complex, seasonal oscillation in local salinity and temperature can help to explain this co-occurrence when combined with species specialization in relation to these factors (Gómez et al., 1997; Montero-Pau et al., 2011; Gabaldón et al., 2015) so that cryptic species have seasonal differences but overlapping distributions (Gómez et al., 1995; 2002a; 2007; Ortells et al., 2003). However, coexistence may also be mediated by subtler niche differentiation. Thus, it has been reported that cryptic rotifer species differing in body size show (1) differential exploitative competitive ability based in resource (microalgae) use partitioning and (2) differential susceptibility to predation (Ciros-Pérez et al., 2001, 2004; Lapesa et al., 2002, 2004). Nevertheless, in species of the complex that are extremely similar in size, coexistence is favored by both differences in their response to fluctuating abiotic salinity and life-history traits related to diapause (Montero-Pau et al., 2011; Gabaldón et al., 2013, 2015; Gabaldón \& Carmona, 2015). On one hand, investment in diapause by a population gives short-term advantages to its competitors; for instance, such investment by a superior competitor may provide an opportunity for coexistence to inferior ones (Montero-Pau \& Serra, 2011). On the other hand, diapausing eggs $\mathrm{Cwhich}$ are insensitive to competition - allow for the temporal escape from competition as they wait in the sediment for a favorable time window in the water column (e.g., Gabaldón et al., 2015).

\section{POPULATION DIFFERENTATION AND LOCAL ADAPTATION IN ROTIFERS}

As in many other taxa, the study of population differentiation and local adaptation in rotifers sheds light on several crucial topics in ecology and evolution. First, it provides signatures of an evolutionary past, as evidenced by phylogeography studies (i.e., the phylogenetic analysis of geographic patterns; Gómez et al., 2000; 2002b; 2007; Campillo et al., 2011a). Second, it identifies the impact of natural selection (1) on the formation and persistence of populations by distinguishing the effects of local adaptation from those of genetic drift (Campillo et al., 2009; Franch-Grass et al., 2017a) and (2) on the temporal patterns - either periodic or non-periodicof genetic change. Third, population differentiation is the first step in what might end in speciation. Last but not least, as stated above, such studies may uncover the existence of cryptic speciation (Mills et al., 2016).

\section{Intrapopulation studies}

The within-population genetic diversity in cyclically parthenogenetic rotifers, as assessed from molecular marker studies, is typically very high (Gómez \& Carvalho, 2000; Ortells et al., 2006; Montero-Pau et al., 2017). This finding is expected due to their large effective population sizes 
and suggests that local populations do not suffer from bottlenecks. In fact, diapause, as a potential bottleneck, does not work in this way, likely because the abundance of diapausing eggs in sediment banks is on the order of millions even in small ponds (García-Roger et al., 2006b; Montero et al., 2017). Allele frequencies in the water column often show deviations from Hardy-Weinberg expectations (HWE; Gómez \& Carvalho, 2000; Ortells et al., 2006). This might be due to the Wahlund effect (i.e., a reduction in the overall heterozygosity of a population as a result of the subpopulation structure) if the genotypes in the water column are a result of those from diapausing eggs in the sediment bank produced both at different times and under different selection pressures. Alternatively, deviation from HWE could be the result of clonal selection during parthenogenetic proliferation. Gómez \& Carvalho (2000) demonstrated clonal selection by the end of the growing season, and Ortells et al. (2006), by comparing different populations, found a correlation between (1) the clonal diversity harbored by a population and (2) the duration of the growing season. Both studies reported high genetic diversity at the start of the growing season, whereas allele frequencies strongly deviated from those expected from genetic equilibrium by the end of the season. These studies suggest that the hatching of diapausing eggs provides high genotypic diversity when the population is established at the start of the growing season. However, this diversity is eroded by clonal selection during parthenogenetic proliferation (i.e., the longer the growing season, the lower the genetic diversity).

Fluctuating selection seems to act in some cases and traits. For instance, Carmona et al. (2009) reported a decrease in the propensity for sexual reproduction over the growing season as a result of the short-term costs of sex and diapause (i.e., a decreased rate of parthenogenetic proliferation). This selection for low investment in sex should reverse between growing seasons, as diapausing eggs are essential for survival during adverse periods (see above). The occurrence of fluctuating selection with a repeated annual pattern was also suggested by Papakostas et al. (2013). In this study, genotypes of a single species in a single locality clustered into groups with strong genetic divergence and differential temporal distribution, suggesting differential seasonal specialization. This study opens a window to the possibility of allochronic sympatric speciation in zooplankters, a hypothesis that was formulated a long time ago (Lynch, 1984).

\section{Interpopulation studies: population differenti- ation, local adaptation and phylogeographic structure}

The traditional view regarding small $(<1 \mathrm{~mm})$ organisms states that, due to their large dispersal capability, (1) these species do not present biogeographic restrictions and should lack geographic structure (Finlay, 2002) and (2) the populations of a species should be connected by gene flow, hindering geographic speciation. This view has been challenged by the high genetic differentiation found in many continental zooplankters after assessments using molecular markers. For instance, species of the genus Brachionus show strong genetic differentiation among populations, even among those living in nearby localities (Gómez et al., 2002; Derry et al., 2003; Campillo et al., 2009; Franch-Gras et al., 2017a). Gene flow seems to be so restricted that it has not blurred the signature of historical events. Consistently, phylogeographic analyses have shown that rotifer populations in the Iberian Peninsula exhibit a within-species differentiation structure that might reflect the impact of Pleistocene glaciations (Gómez et al., 2000; 2002b; Campillo et al., 2011a). Accordingly, this structure seems to be due to the serial recolonization of ponds from glacial refugia located in southern Spain. Historical effects are diluted only at small geographic scales, likely due to the intense dynamics of extinction and recolonization from neighboring localities that are still genetically differentiated (Montero-Pau et al., 2017).

The disagreement between the traditional view and the empirical evidence stressed above has been termed the "dispersal-gene flow paradox" (i.e., high dispersal capacity contrasts with pronounced genetic differentiation among neighboring populations; De Meester et al., 2002). The hypothetical explanation for this paradox is 
based on strong persistent founder effects due to the combination of (1) populations founded by a few individuals - with the important corresponding sample effect, (2) fast proliferation, and (3) the accumulation of large diapausing egg banks. These factors would quickly create large population sizes after the establishment of a population from a few colonizers such that later immigrants are diluted within a large population and have little effect. Under these conditions, the time necessary to reach the migration-drift equilibrium would be so long that it would not be observed due to the interference of major historical changes (e.g., speciation, climate change). Moreover, it has been postulated that local adaptation can also quickly occur, reinforcing barriers against immigration ("the monopolization hypothesis", De Meester et al., 2002). Rotifers support some assumptions of these explanations. At a large geographical scale, Gómez et al. (2002a) found levels of population differentiation that were consistent with initial colonization by single resting eggs from neighboring populations. Additionally, the establishment of populations of B. plicatilis in newly created ponds in a restored marshland followed by Badosa et al. (2017) revealed a low number of founding clones. Nevertheless, colonization might exhibit rather complex dynamics. The effect of the very first founders can eventually decline if later immigrants have a selective advantage over the highly inbred local residents, an effect experimentally demonstrated in B. plicatilis by Tortajada et al. (2010). Therefore, the establishment of a viable population might occur during a time window scaled by a decrease in inbreeding depression due to an increase in genetic diversity. In addition, diapausing egg banks may initially be relatively small or lack ecologically relevant variation, reducing their buffering role against immigrant genes. In their study, Badosa et al. (2017) consistently found effective gene flow soon after foundation. In rotifers, differentiation in molecular markers and differentiation in ecologically relevant traits are poorly correlated (Campillo et al., 2011b). Thus, local adaptation does occur in rotifers, but it seems to be less important than persistent founder effects in preventing effective gene flow (i.e., in causing population differentiation). This could differ from what has been observed in cladocerans, in which population sizes are typically lower than those in rotifers; cladocerans also live in relatively more constant environments, indicating that local adaptation is a factor in the observed population differentiation in that taxon (De Meester et al., 2004).

Due to the effective clonal selection that occurs during the parthenogenetic phase and the decrease in genetic variation that occurs through recurrent sexual recombination, cyclical parthenogens are expected to be prone to local adaptation (Lynch \& Gabriel, 1983), particularly because, as stated above, the effective gene flow is low. Research on local adaptation in rotifers has benefited from the potential to perform common garden experiments. Ideally, reciprocal transplant experiments demonstrate local adaptation by showing that the "local vs. foreign" (i.e., the average fitness of local genotypes is higher than the average fitness of foreigners) or "home vs. away" (i.e., the average fitness of a genotype is higher in its native locality than in other localities) criterion is fulfilled (see Kawecki \& Ebert, 2004). However, this kind of experiment is logistically complicated, as it requires introducing genotypes from natural populations from each of $\geq 2$ environments into the others. As an alternative, common garden experiments have allowed the study of the fitness response of different rotifer genotypes when cultured under laboratory conditions mimicking the typical values of very specific environmental variables in natural populations. Campillo et al. (2011b) measured fitness components (e.g., the intrinsic rate of increase) in the laboratory under combined salinity and temperature conditions in B. plicatilis populations sampled from six localities. The variation found therein was associated with the actual conditions of the ponds from which they were sampled, and a clear case of local adaptation to high salinity was reported (Campillo et al., 2011b). This adaptation to local salinity is consistent with the fact that species specialization exists in relation to this parameter in rotifers inhabiting brackish waters (Miracle \& Serra, 1989). Campillo et al. (2011) also found signatures of life cycle adap- 
tations to habitat uncertainty. A long time ago, rotifer populations in unpredictable habitats were proposed to invest early and continuously in sexual reproduction during their annual growth cycle (a bet-hedging strategy; Carmona et al., 1995; Serra \& King, 1999; Serra et al., 2004, 2005), but variation in traits could not be correlated with an estimate of unpredictability. Recently, Franch-Gras et al. (2017b) used time series obtained from remote sensing data to estimate the degree of unpredictability in inland ponds of eastern Spain, as indicated by the long-term fluctuations in the water surface area of the ponds. After the observation of a rather wide range in unpredictability, they studied life-history traits associated with diapause (Franch-Gras et al., 2017a). One of the hypotheses addressed was a higher propensity for sex with increasing unpredictability, since early sex means early investment in diapausing eggs - at the cost of decreasing the rate of clonal proliferation-, and investing early in diapause is needed to prevent growing seasons from being unexpectedly short. Their results showed the expected positive correlation between habitat unpredictability and the propensity for sex, this being one of the few studies testing bet-hedging strategies allowing adaptation to unpredictable environmental fluctuations. This adaptation is possible because, as observed in a recent study using experimental evolution, rotifers quickly evolve bet-hedging strategies in response to environmental unpredictability (Tarazona et al., 2017).

Recently, Declerck et al. (2015) took a further step in the study of adaptation to the local environment by means of what was called a common garden transplant approach. In their study, naturally derived populations of $B$. calyciflorus were first subjected to two contrasting selective regimes related to $\mathrm{P}$ enrichment $(\mathrm{P}$ poor vs. $\mathrm{P}$ rich) in chemostats. Later, rotifers with different genotypes from each selective regime were grown under both P-poor and P-rich conditions, and population performance estimates (growth, yield, grazing pressure) were used to demonstrate rapid adaptation (within a growing season) in the populations. This observation is somewhat consistent with the "local vs. foreign" criterion mentioned above.

\section{PROSPECTS}

In this review, we have shown how cyclically parthenogenetic rotifers are remarkable because of the features of their reproductive biology, which have enabled (1) exceptional experimental flexibility and control, (2) the collection of an extensive amount of both ecological and life-history trait data for many rotifer species, and (3) their use in tests of specific hypotheses in population and evolutionary ecology studies. Several of these studies open the door to a series of questions concerning their genetics. Now, we envision the most promising opportunities for investigation provided by recent genomic tools and the development of sophisticated culturing techniques.

On one hand, the current and future availability of rotifer genome sequences (Flot et al., 2013; Franch-Gras et al., 2017a) are expected to revolutionize the field of evolutionary ecology studies in animals that are not genetic models (Declerck \& Papakostas, 2017). Genome and transcriptome sequencing may also result in unprecedented advances in population genotyping and in the detection of genes related to any biological process of interest. As evidence of this potential, some studies have already been successful in identifying genes related to diapause (Denekamp et al., 2009; 2011; Clark et al., 2012), reproductive modes (Hanson et al., 2013a; 2013b) and aging (Gribble \& Mark Welch, 2017). The regulation of the asexual and sexual phases of cyclical parthenogenesis is addressable using these tools. Here, we call for the need to couple such molecular approaches with concurrent changes in physiology, behavior or life history for a complete understanding of adaptation.

On the other hand, the large population sizes and short generation times of rotifers are expected to allow the testing of evolutionary hypotheses in the laboratory (i.e., to control for confounding factors), a methodological approach that is impeded in other animals due to practical constraints. Experimental evolution has the potential to demonstrate evolution in action and to quantify the strength of natural selection against that of other evolutionary forces. We envision that among the tests of these hypotheses will be additional studies on the evolution of sex, 
speciation processes, and rapid evolution in eco-evolutionary dynamics (Fussmann et al., 2007; Post \& Palkovacs, 2009; Ellner et al., 2013; Declerck \& Papakostas, 2017). Potential also exists to combine laboratory results with resurrection ecology studies in natural populations.

Combining genomics and experimental evolution studies is also a promising avenue of research. Finding the genomic signature of rapid evolutionary adaptations may provide insights into why some traits evolve faster than others (Tarazona et al., 2017). From our perspective, the application of these tools to rotifer research will allow the (re)formulating and testing of old and new hypotheses in the field of theoretical evolutionary ecology and population biology to continue the path opened by Professor M. R. Miracle.

\section{ACKNOWLEDGEMENTS}

We are grateful to the organizers of this special issue of Limnetica in tribute to Maria Rosa Miracle for considering our contribution. This study was supported by the Spanish Plan Nacional de Investigación Científica, Desarrollo e Innovación Tecnológica from the Spanish Ministry of Economy and Competitiveness grant CGL2015-65422-P (co-financed by FEDER funds, European Union).

\section{REFERENCES}

ARÁNGUIZ-ACUÑA， A., R. RAMOS-JILIBERTO \& S. NANDINI. 2010. Benefits, costs and reactivity of inducible defences: an experimental test with rotifers. Freshwater Biology, 55: 2114-2122. DOI: 10.1111/j.1365-2427. 2010.02471.X

ATKINSON, D. 1994. Temperature and organism size: a biological law for ectotherms? Advances in Ecological Research, 25: 1-58. DOI: 10.1016/S0065-2504(08)60212-3.

BADOSA, A., D. FRISCH, A. G. GREEN, C. RICO \& A. GÓMEZ. 2017. Isolation mediates persistent founder effects on zooplankton colonisation in new temporary ponds. Scientific Reports, 7: 43983. DOI: 10.1038/srep43983.

BECKS, L., \& A. F. AGRAWAL. 2010. Higher rates of sex evolve in spatially heterogeneous environments. Nature, 468: 89-92. DOI: 10.1038/nature09449

BECKS, L., \& A. F. AGRAWAL. 2012. The evolution of sex is favoured during adaptation to new environments. PLOS ONE, 10: e1001317. DOI: 10.1371/journal.pbio. 1001317

BELL, G. 1982. The masterpiece of nature: The evolution and genetics of sexuality. California Univ. Press, Berkeley, CA.

BIRKY, C. W. 1967. Studies on the physiology and genetics of the rotifer, Asplanchna. III. Results of outcrossing, selfing, and selection. Journal of Experimental Zoology Part A: Ecological Genetics and Physiology, 164(1): 105-115.

BLACK, R. W. \& L. B. SLOBODKIN, 1987. What is cyclomorphosis. Freshwater Biology, 18: 373-378. DOI: 10.1111/j.1365-2427. 1987.tb01321.x

BOORAS, M. E. \& W. N. BENNETT. 1988. Steady-state rotifer growth in a two-stage, computer-controlled turbidostat. Journal of Plankton Research, 10: 1023-1038. DOI: 10.1023/plankt/10.5.1023

BRENDONCK, L. \& L. DE MEESTER. 2003. Egg banks in freshwater zooplankton: evolutionary and ecological archives in the sediment. Hydrobiologia, 491(1-3): 65-84. DOI: $10.1023 / \mathrm{A}: 1024454905119$

CAMPILLO S., E. M. GARCÍA-ROGER, M. J. CARMONA, A. GÓMEZ \& M. SERRA. 2009. Selection on life-history traits and genetic population divergence in rotifers. Journal of Evolutionary Biology, 22: 2542-2553. DOI: 10.1111/j.1420-9101.2009.01871.X

CAMPILLO, S., M. SERRA, M. J. CARMONA \& A. GÓMEZ. 2011a. Widespread secondary contact and new glacial refugia in the halophilic rotifer Brachionus plicatilis in the Iberian Peninsula. PLOS ONE, 6(6): e20986. DOI: 10.1371/journal.pone.0020986

CAMPILLO S., E. M. GARCÍA-ROGER, M. J. CARMONA \& M. SERRA. 2011b. Local adaptation in rotifer populations. Evolutionary Ecology, 25(4): 933-947. DOI: 10.1007/s10682-010-9447-5

CARMONA, M. J., M. SERRA, \& M. R. MIRACLE. 1989. Hydrobiologia, 186: 325-330. DOI: $10.1007 / \mathrm{BF} 00048928$ 
CARMONA, M. J. \& M. SERRA. 1991. Comparative total protein and demographic patterns of mictic and amictic female rotifers. Verhandlungen des Internationalen Verein Limnologie, 24: 2754-2759. DOI: 10.1080/ 03680770.1989.11899150

CARMONA, M. J., M. SERRA \& M. R. MIRACLE. 1993. Relationships between mixis in Brachionus plicatilis and preconditioning of culture medium by crowding. Hydrobiologia, 83: 145-152. DOI: 10.1007/978-94-0111606-0 19

CARMONA, M. J., M. SERRA \& M. R. MIRACLE. 1994. Effect of population density and genotype on life-history traits in the rotifer Brachionus plicatilis OF Müller. Journal of Experimental Marine Biology and Ecology, 182(2): 223-235. DOI: 10.1016/0022-0981 (94)90053-1

CARMONA, M. J., N. DIMAS-FLORES, E. M. GARCIA-ROGER \& M. SERRA. 2009. Selection of low investment in sex in a cyclically parthenogenetic rotifer. Journal of Evolutionary Biology, 22: 1975-1983. DOI: 10.1111/j.1420-9101.2009.01811.x

CHARIN, N. N., 1947. O novom vide kolovratki is roda Brachionus. Doklady Akademii Nauk SSSR 56: 107-108.

CIROS-PÉREZ, J., A. GÓMEZ \& M. SERRA. 2001. On the taxonomy of three sympatric sibling species of the Brachionus plicatilis (Rotifera) complex from Spain, with the description of B. ibericus n.sp. Journal of Plankton Research, 23: 1311-1328. DOI: 10.1093/plankt/23.12.1311

CIROS-PÉREZ, J., M. J. CARMONA, S. LAPESA \& M. SERRA. 2004. Predation as a factor mediating resource competition among rotifer sibling species. Limnology and Oceanography, 49 (1): 40-50. DOI: 10.4319/1o.2004. 49.1.0040

CLARK, M. S., N. Y. DENEKAMP, M. A. S. THORNE, R. REINHARDT, M. DRUNGOWSKI, M. W. ALBRECHT, S. KLAGES, A. BECK, M. KUBE \& E. LUBZENS. 2012. Long-term survival of hydrated resting eggs from Brachionus plicatilis. PLOS ONE, 7: e29365. DOI: 10.1371/journal.pone.0029365

CLEMENT, P., \& E. WURDAK. 1991. Rotifera.
In: Microscopic anatomy of invertebrates, vol. 4. Aschelmintes. F.W. Harrison \& E.E. Ruppert (eds.): 219-297. Wiley-Liss, New York.

DAHMS, H. U., A. HAGIWARA \& LEE J. S. 2011. Ecotoxicology, ecophysiology, and mechanistic studies with rotifers. Aquatic toxicology, 101(1): 1-12. DOI: 10.1016/j.aquatox.2010. 09.006

DECLERCK, S. A. J., A. R. MALO, S. DIEHL, D. WAASDORP, K. D. LEMMEN, K. PROIOS \& S. PAPAKOSTAS. 2015. Rapid adaptation of herbivore consumers to nutrient limitation: eco-evolutionary feedbacks to population demography and resource control. Ecology Letters, 18: 553-562. DOI: 10.1111/ele. 12436

DECLERCK, S. A., \& PAPAKOSTAS, S. 2017. Monogonont rotifers as model systems for the study of micro-evolutionary adaptation and its eco-evolutionary implications. Hydrobiologia, 796(1): 131-144. DOI: 10.1007/s10750016-2782-y

DE MEESTER, L., A. GÓMEZ, B. OKAMURA \& K. SCHWENK. 2002. The Monopolization Hypothesis and the dispersal-gene flow paradox in aquatic organisms. Acta oecologica, 23(3): 121-135. DOI: 10.1016/S1146-609X (02)01145-1

DE MEESTER, L., A. GÓMEZ, \& J-C. SIMON. 2004. Evolutionary and ecological genetics of cyclical parthenogens. In: Evolution: From molecules to ecosystems. A. Moya, \& E. Font (eds.): 122-134. Oxford University Press.

DENEKAMP, N. Y., M. A. THORNE, M. S. CLARK, M. KUBE, R. REINHARDT \& E. LUBZENS. 2009. Discovering genes associated with dormancy in the monogonont rotifer Brachionus plicatilis. BMC Genomics, 10: 108. DOI: 10.1186/1471-2164-10-108

DENEKAMP, N. Y., R. REINHARDT, M. W. ALBRECHT, M. DRUNGOWSKI \& $\mathrm{M}$. KUBE. 2011. The expression pattern of dormancy-associated genes in multiple life-history stages in the rotifer Brachionus plicatilis. Hydrobiologia, 662: 51-63. DOI: 10.1007/s10750-010-0518-y

DERRY, A. M., N. HEBERT, D. PAUL \& E. E. PREPAS. 2003. Evolution of rotifers in saline and subsaline lakes: a molecular phylogenetic 
approach. Limnology and Oceanography, 48 (2), 675-685. DOI: 10.2307/3096570

D'SOUZA, T. G. \& N. K. MICHIELS. 2010. The costs and benefits of occasional sex: Theoretical predictions and a case study. Journal of Heredity, 101: 34-41. DOI: 10.1093/jhered/esq005

ELLNER, S. P. 2013. Rapid evolution: from genes to communities, and back again? Functional Ecology, 27(5): 1087-1099. DOI: 10.1111/1365-2435.12174

ENESCO, H. E. 1993. Rotifers in aging research: Use of rotifers to test various theories of aging. Hydrobiologia, 255/256: 59-70. DOI: 10.1007/BF00025821

EVANS, M. E. K. \& J. J. DENNEHY. 2005. Germ banking: bet-hedging and variable release from egg and seed dormancy. The Quarterly Review of Biology, 80 (4): 431-451. DOI: $10.1086 / 498282$

FONTANETO D., M. KAYA, E. A. HERNIOU, T. G. BARRACLOUGH. 2009. Extreme levels of hidden diversity in microscopic animals (Rotifera) revealed by DNA taxonomy. Molecular Phylogenetics and Evolution 53:182-189. DOI: 10.1016/j.ympev.2009.04.011

FONTANETO, D. \& W. DE SMET. 2015. Rotifera. In: Handbook of zoology, Gastrotricha and Gnathifera A. Schmidt-Rhaesa (ed.): 216-300. De Gruyter, Berlin.

FRANCH-GRAS, L., E. M. GARCÍA-ROGER, M. SERRA \& M. J. CARMONA. 2017a. Adaptation in response to environmental unpredictability. Proceedings of the Royal Society B, 284 (1868): 20170427. DOI: 10.1098/rspb.2017.0427

FRANCH-GRAS, L., E. M. GARCÍA-ROGER, B. FRANCH, M. J. CARMONA \& M. SERRA. 2017b. Quantifying unpredictability: A multiple-model approach based on satellite imagery data from Mediterranean ponds. PLOS ONE, 12(11): e0187958. DOI: 10.1371/journal.pone.0187958

FRANCH-GRAS, L., C. HAHN, E. M. GARCÍA-ROGER, M. J. CARMONA, M. SERRA \& A. GÓMEZ, 2018. Genomic signatures of local adaptation to the degree of environmental predictability in rotifers, Scientific reports, 8(1): 16051. DOI: 10.1038/s41598- 018-34188-y

FUSCO, G. \& A. MINELLI. 2010. Phenotypic plasticity in development and evolution: facts and concepts. Philosophical Transactions of the Royal Society B-Biological Sciences, 365: 547-556. DOI: 10.1098/rstb.2009.0267

FUSSMANN, G. F., S. P. ELLNER \& N. G. HAIRSTON. 2003. Evolution as a critical component of plankton dynamics. Proceedings of the Royal Society Series B-Biological Sciences, 270: 1015-1022. DOI: 10.1098/ rspb.2003.2335

FUSSMANN, G. F., M. LOREAU \& P. A. ABRAMS. 2007. Eco-evolutionary dynamics of communities and ecosystems. Functional Ecology, 21(3): 465-477. DOI: 10.1111/j. 1365-2435.2007.01275.x

FUSSMANN, G. F. 2011. Rotifers: excellent subjects for the study of macro-and microevolutionary change. Hydrobiologia, 662(1): 11-18. DOI: 10.1007/s10750-010-0515-1

GABALDÓN, C., J. MONTERO-PAU, M. SERRA \& M. J. CARMONA. 2013. Morphological similarity and ecological overlap in two rotifer species. PLOS ONE, 8: e57087. DOI: 10.1371/journal.pone.0057087

GABALDÓN, C., \& M. J. CARMONA. 2015. Allocation patterns in modes of reproduction in two facultatively sexual cryptic rotifer species. Journal of Plankton Research, 37(2): 429-440. DOI: 10.1093/plankt/fbv012

GABALDÓN, C., M. SERRA, M. J. CARMONA \& J. MONTERO-PAU. 2015. Life-history traits, abiotic environment and coexistence: the case of two cryptic rotifer species. Journal of Experimental Marine Biology and Ecology, 465: 142-152. DOI: 10.1016/j. jembe.2015.01.016

GABALDÓN, C., D. FONTANETO, M. J. CARMONA, J. MONTERO-PAU \& M. SERRA. 2017. Ecological differentiation in cryptic rotifer species: what we can learn from the Brachionus plicatilis complex. Hydrobiologia 796: 7-18. DOI: 10.1007/s10750-016-2723-9.

GALINDO, M. D., C. GUISANDE \& J. TOJA. 1993. Reproductive investment of several rotifer species. Hydrobiologia, 255(1): 317-324. DOI: 10.1007/BF00025854

GARCÍA-ROGER, E. M., M. J. CARMONA \& 
M. SERRA, 2006a. Hatching and viability of rotifer diapausing eggs collected from pond sediments. Freshwater Biology, 51: 1351-1358. DOI: 10.1111/j.1365-2427.2006. 01583.x

GARCÍA-ROGER, E. M., M. J. CARMONA \& M. SERRA. 2006b. Patterns in rotifer diapausing egg bank: density and viability. Journal of Experimental Marine Biology and Ecology, 336: 198-210. DOI: 10.1016/j.jembe.2006. 05.009

GRIBBLE, K. E. \& D. B. MARK WELCH. 2017. Genome-wide transcriptomics of aging in the rotifer Brachionus manjavacas, an emerging model system. BMC Genomics. 18(1): 217. DOI: $10.1186 / \mathrm{s} 12864-017-3540-\mathrm{x}$

GILBERT, J. J. 1974. Dormancy in rotifers. Transactions of the American Microscopical Society, 93 (4): 490-513. DOI: $10.2307 / 3225154$

GILBERT, J. J. 1983. Rotifera. In: Reproductive biology of invertebrates, vol. 1. K. G. Adiyodi \& R. G. Adiyodi (eds.): 181-209. Wiley and Sons, New York.

GILBERT, J. J. 2003. Environmental and endogenous control of sexuality in a rotifer life cycle: developmental and population biology. Evolution \& Development, 5(1): 19-24.

GILBERT, J. J. 2009. Predator-specific inducible defenses in the rotifer Keratella tropica. Freshwater Biology, 54: 1933-1946. DOI: 10.1111/j.1365-2427.2009.02246.x

GILBERT, J. J. 2011. Induction of different defences by two enemies in the rotifer Keratella tropica: response priority and sensitivity to enemy density. Freshwater Biology, 56: 926-938. DOI: 10.1111/j.1365-2427. 2010.02538.x

GILBERT, J. J. 2013. The cost of predator-induced morphological defense in rotifers: experimental studies and synthesis. Journal of Plankton Research, 35: 461-472. DOI: 10.1093/plankt/fbt017

GILBERT, J. J. 2017. Non-genetic polymorphisms in rotifers: environmental and endogenous controls, development, and features for predictable or unpredictable environments. Biological Reviews, 92: 964-992. DOI: 10.1111/brv.12264

GILBERT, J. J. 2018. Morphological variation and its significance in a polymorphic rotifer: environmental, endogenous, and genetic controls. BioScience 68: 169-181. DOI: 10.1093/biosci/bix162

GÓMEZ, A. 2005. Molecular ecology of rotifers: from population differentiation to speciation. Hydrobiologia, 546: 83-99. DOI: 10.1007/ 1-4020-4408-9 7

GÓMEZ, A., M. TEMPRANO \& M. SERRA, M. 1995. Ecological genetics of a cyclical parthenogen in temporary habitats. Journal of Evolutionary Biology, 8:601-622. DOI: 10.1046/j.1420-9101.1995.8050601.x

GÓMEZ, A., M. J. CARMONA \& M. SERRA. 1997. Ecological factors affecting gene flow in the Brachionus plicatilis complex (Rotifera). Oecologia, 111(3): 350-356. DOI: 10.1007/s004420050245

GÓMEZ, A., C. CLABBY \& G. R. CARVALHO. 1998. Isolation and characterization of microsatellite loci in a cyclical parthenogenetic rotifer, Brachionus plicatilis. Molecular Ecology, 7: 1619-1621. DOI: 10.1046/j.1365294X.1998.00474.x

GÓMEZ, A., G. R. CARVALHO \& D. H. LUNT. 2000. Phylogeography and regional endemism of a passively dispersing zooplankter: mitochondrial DNA variation in rotifer resting egg banks. Proceedings of the Royal Society Series B-Biological Sciences, 267: 2189-2197. DOI: $10.1098 / \mathrm{rspb} .2000 .1268$

GÓMEZ, A., M. SERRA, G. R. CARVALHO \& D. H. LUNT. 2002a. Speciation in ancient cryptic species complexes: evidence from the molecular phylogeny of Brachionus plicatilis (Rotifera). Evolution, 56: 1431-1344. DOI: 10.1554/0014-3820(2002)056[1431:SIACSC] 2.0.CO;2

GÓMEZ, A., G. A. ADCOCK, D. H. LUNT \& G. R. CARVALHO. 2002b. The interplay between colonisation history and gene flow in passively dispersing zooplankton: microsatellite analysis of rotifer resting egg banks. Journal of Evolutionary Biology, 15:158-171. DOI: $10.1046 / j .1420-9101.2002 .00368 . x$

GÓMEZ, A., J. MONTERO-PAU, J., D. H. LUNT, M. SERRA \& S. CAMPILLO. 2007. Persistent genetic signatures of colonization in Brachionus manjavacas rotifers in the 
Iberian Peninsula. Molecular Ecology, 16: 3228-3240. DOI: 10.1111/j.1365-294X. 2007.03372.x

GRIBBLE, K. E., O. KAIDO, G. JARVIS, G. \& D. B. MARK WELCH. 2014. Patterns of intraspecific variability in the response to caloric restriction. Experimental Gerontology, 51:28-37. DOI: 10.1016/j.exger.2013.12.005

HAGIWARA, A., K. SUGA, A. AKAZAWA, T. KOTANI, \& Y SAKAKURA. 2007. Development of rotifer strains with useful traits for rearing fish larvae. Aquaculture, 268(1-4): 44-52. DOI: 10.1016/j.aquaculture.2007. 04.029

HAIRSTON, N. G., JR., W. LAMPERT, C. E. CÁCERES, C. L. HOLTMEIER, L. J. WEIDER, U. GAEDKE, J. M. FISCHER, J. A. FOX, \& D. M. POST. 1999. Rapid evolution revealed by dormant eggs. Nature, 401: 446. DOI: $10.1038 / 46731$

HALBACH, U. 1970. Influence of temperature on population dynamics of the rotifer Brachionus calyciflorus Pallas. Oecologia, 4:176-207. DOI: 10.1007/BF00377100

HALBACH, U. \& J. JACOBS. 1971. Seasonal selection as a factor in rotifer cyclomorphosis. Naturwissenschaften, 57: 1-2.

HANSON, S. J., C. P. STELZER, D. B. MARK WELCH \& J. M. LOGSDON, JR. $2013 \mathrm{a}$. Comparative transcriptome analysis of obligately asexual and cyclically sexual rotifers reveals genes with putative functions in sexual reproduction, dormancy, and asexual egg production. BMC Genomics, 19: 412 . DOI: $10.1186 / 1471-2164-14-412$

HANSON, S. J., A. M. SCHURKO, B. HECOX-LEA, D. B. MARK WELCH, C. - P. STELZER \& J. M. LOGSDON. 2013b. Inventory and phylogenetic analysis of meiotic genes in monogonont rotifers. Journal of Heredity, 104: 357-370. DOI: 10.1093/jhered/est011

HEBERT, P. D. N. 1987. Genotypic characteristics of cyclic parthenogens and their obligately asexual derivatives. In: The Evolution of Sex and Its Consequences. S. C. Stearns (ed.): 175-195. Birkhäuser, Basel.

HICKMAN, C., L. ROBERTS \& A. LARSON. 1997. Zoología. Principios integrales. McGraw-Hill Interamericana, Madrid, Spain.
HURST L. D. \& J. R. PECK. 1996. Recent advances in understanding of the evolution and maintenance of sex. Trends in Ecology and Evolution, 11:46-52. DOI: 10.1016/01695347(96)81041-X

HUTCHINSON, G. E. 1959. Homage to Santa Rosalia or why are there so many kinds of animals? American Naturalist, 93: 145-159. DOI: $10.1086 / 282070$

HUTCHINSON, G. E. 1979. An introduction to population ecology. Yale University Press. New Haven.

HWANG, D. S., H. U. DAHMS, H. G. PARK \& J. S. LEE, 2013. A new intertidal Brachionus and intrageneric phylogenetic relationships among Brachionus as revealed by allometry and CO1-ITS1 gene analysis. Zoological Studies, 52: 792 1-10. DOI: 10.1186/1810-522X-52-13

JOHNSTON, R. K \& T. W. SNELL. 2016. Moderately lower temperatures greatly extend the lifespan of Brachionus manjavacas (Rotifera): Thermodynamics or gene regulation? Experimental Gerontology, 78:12-22. DOI: 10.1016/j.exger.2016.02.014

KAWECKI, T. J \& D. EBERT. 2004. Conceptual issues in local adaptation. Ecology Letters, 7:1225-1241. DOI: 10.1111/j.1461-0248. 2004.00684.x

KING, C. E. 1970. Comparative survivorship and fecundity of mictic and amictic female rotifers. Physiological Zoology, 43 (3): 206-212. DOI: 10.1086/physzool.43.3.30155530

KING, C. E. \& M. R. MIRACLE. 1980. A perspective on aging in rotifers. Hydrobiologia, 73: 13-19. DOI: 10.1007/978-94-0099209-2 2

KOSTOPOULOU, V., M. J. CARMONA \& P. DIVANACH. 2012. The rotifer Brachionus plicatilis: an emerging bio-tool for numerous applications. Journal of Biological Research, 17: 97-112.

KOTANI, T., M. OZAKI, K. MATSUOKA, T. W. SNELL \& A. HAGIWARA. 2001. Reproductive isolation among geographically and temporally isolated marine Brachionus strains. Hydrobiologia, 153: 283-290. DOI: 10.1007/978-94-010-0756-6_37

LAKATOS, I. 1970. Falsification and the methodology of scientific research programmes. 
In: Criticism and the growth of knowledge. In: Lakatos, I \& A. Musgrave (eds). Cambridge University Press, Cambridge.

LAPESA, S., T. W. SNELL, D. FIELDS \& M. SERRA. 2002. Predatory interactions between a cyclopoid copepod and three sibling rotifer species. Freshwater Biology, 47: 1685-1695. DOI: 10.1111/j.1365-2427.2004.01249.x

LAPESA, S., T. W. SNELL, D. FIELDS \& M. SERRA. 2004. Selective feeding of Arctodiaptomus salinus (Copepoda, Calanoida) on co-occurring sibling rotifer species. Freshwater Biology, 49: DOI: 1053-1061. 10.1111/j. 1365-2427.2004.01249.x

LEASI, F., C. Q. TANG, W. H. DE SMET \& D. FONTANETO. 2013. Cryptic diversity with wide salinity tolerance in the putative euryhaline Testudinella clypeata (Rotifera, Monogononta). Zoological Journal of the Linnean Society, 168: 17-28. DOI: 10.1111/ zoj. 12020

LUBZENS, E., A., TANDLER \& G. MINKOFF. 1989. Rotifers as food in aquaculture. Hydrobiologia, 186(1): 387-400. DOI: 10.1007/ BF00048937

LUBZENS, E., O. ZMORA \& Y. BARR. 2001. Biotechnology and aquaculture of rotifers. Hydrobiologia, 446/447: 337-353. DOI: 10.1023/A:1017563125103

MARK WELCH, D. B. 2000. Evidence from a protein-coding gene that acanthocephalans are rotifers. Invertebrate Biology, 119(1): 17-26. DOI: $10.1111 / \mathrm{j} .1744-7410.2000 . t b 00170 . x$

MARK WELCH, D. B. \& J. L. MARK WELCH. 2005. The potential of genomic approaches to rotifer ecology. Hydrobiologia, 546: 101-108. DOI: 10.1007/1-4020-4408-9 8

MATTHEWS, B., L. DE MEESTER, C. G. JONES, B. W. IBELINGS, T. J. BOUMA, V. NUUTINEN, J. VAN DE KOPPEL \& J. ODLING-SMEE. 2014. Under niche construction: an operational bridge between ecology, evolution, and ecosystem science. Ecological Monographs, 84: 245-263. DOI: 10.1890/13-0953.1

MAYNARD SMITH, J. 1978. The evolution of sex. Cambridge University Press, Cambridge, U.K.

MCINTOSH, R. P. 1985. The background of ecology. Cambridge University Press, Cambridge.

MCDONALD, R. B. 2013. Biology of aging. Garland Science.

MILLS, S., A. ALCÁNTARA-RODRÍGUEZ, J. CIROS-PÉREZ, A. GÓMEZ, A. HAGIWARA, K. H. GALINDO, C. D. JERSABEK, R. MALEKZADEH-VIAYEH, F. LEASI, J. S. LEE, D. B. MARK WELCH, S. PAPAKOSTAS, S. RISS, H. SEGERS, M. SERRA, R. SHIEL, R. SMOLAK, T. W. SNELL, C. -P. STELZER, C. Q. TANG, R. L. WALLACE, D. FONTANETO \& E. J. WALSH. 2016. Fifteen species in one: deciphering the Brachionus plicatilis species complex (Rotifera, Monogononta) through DNA taxonomy. Hydrobiologia, 796: 39-58. DOI: 10.1007/ s10750-016-2725-7

MIRACLE, M. R. 1974. Niche structure in freshwater zooplankton: a principal components approach. Ecology 55: 1306-1316. DOI: 10.2307/1935458

MIRACLE, M. R., M. SERRA, E. VICENTE \& C. BLANCO. 1987. Distribution of Brachionus species in Spanish mediterranean wetlands. Hydrobiologia, 147: 75 -81. DOI: 10.1007/BF00025728

MIRACLE, M. R. \& M. SERRA. 1989. Salinity and temperature influence in rotifer life history characteristics. Hydrobiologia, 186(1): 81-102. DOI: 10.1007/978-94-009-0465-1 11

MONTERO-PAU, J. \& A. GÓMEZ. 2011. Development of genomic resources for the phylogenetic analysis of the Brachionus plicatilis species complex (Rotifera: Monogononta). Hydrobiologia. DOI: 10.1007/s10750-010-0485-3

MONTERO-PAU, J. \& M. SERRA. 2011. Life-cycle switching and coexistence of species with no niche differentiation. PLOS ONE 6(5): e20314. DOI: 10.1371/ journal.pone.0020314

MONTERO-PAU, J., E. RAMOS-RODRIGUEZ, M. SERRA \& A. GÓMEZ. 2011. Long-term coexistence of rotifer cryptic species. PLOS ONE 6(6): e21530. DOI: 10.1371/journal.pone.0021530.

MORA, C., D. P. TITTENSOR, S. ADL, A. G. SIMPSON \& B. WORM. 2011. How many 
species are there on Earth and in the ocean? PLOS ONE, 9(8): e1001127. DOI: 10.1371/ journal.pbio.1001127

MORAN, N. A. 1994. Adaptation and constraint in the complex life cycles of animals. Annual Review of Ecology and Systematics, 25(1): 573-600. DOI:10.1146/annurev.es.25.10194. 003041

MÜLLER, O. F. 1786. Animacula infusoria fluviatilia et marina, quae detexit, systematice descripsit et ad vivum delineari curavit. Havniae [Copenhagen] et Lipsiae [Leipzig]: cura Othonis Fabricii, typis Nicolai Mölleri.

NOGRADY, T., R. L. WALLACE \& T. W. SNELL. 1993. Rotifera. Volume 1: biology, ecology and systematics. Guides to the Identification of the Microinvertebrates of the Continenal Waters of the World, 4. T. Nogrady (ed.). SPB Academic Publishing, The Hague.

OBERTEGGER, U., D. FONTANETO \& G. FLAIM. 2012. Using DNA taxonomy to solve the ecological drivers of plankton diversity: occurrence of Synchaeta (Rotifera, Monogononta) in mountain lakes. Freshwater Biology, 57:1545-1553. DOI: 10.1111/j.1365-2427. 2012.02815.X

ORTELLS, R., T. W. SNELL, A. GÓMEZ \& M. SERRA. 2000. Patterns of genetic differentiation in resting egg banks of a rotifer species complex in Spain. Archiv für Hydrobiologie, 149: 529-551. DOI: 10.1127/archiv-hydrobiol/ 149/2000/529

ORTELLS, R., A. GÓMEZ \& M. SERRA. 2003. Coexistence of rotifer cryptic species: ecological and genetic characterisation of Brachionus plicatilis. Freshwater Biology, 48: 2194-2202. DOI: 10.1046/j.1365-2427. 2003.01159.x

ORTELLS, R., A. GÓMEZ \& M. SERRA. 2006. Effects of duration of the planktonic phase on rotifer genetic diversity. Archiv für Hydrobiologie, 167: 203-216. DOI: 10.1127/00039136/2006/0167-0203

PAPAKOSTAS, S., E. MICHALOUDI, A. TRIANTAFYLLIDIS, I. KAPPAS \& J. ABATZOPOULOS. 2013. Allochronic divergence and clonal succession: two microevolutionary processes sculpturing populations structure of Brachionus rotifers. Hydrobiologia, 700: 33-45. DOI: 10.1007/s10750-0121217-7

PAPAKOSTAS, S., E. MICHALOUDI, K. PROIOS, M. BREHM, L. VERHAGE, J. ROTA, C. PEÑA, G. STAMOU, V. L. PRITCHARD, D. FONTANETO \& S. A. J. DECLERCK. 2016. Integrative taxonomy recognizes evolutionary units despite widespread mitonuclear discordance: evidence from a rotifer cryptic species complex. Systematic Biology, 65: 508-524. DOI: 10.1093/sysbio/syw016

PARK, T. 1946. Some observations on the history and scope of population ecology. Ecological Monographs, 16: 313-320. DOI: $10.2307 / 1961638$

PECK, J. R. \& D. WAXMAN. 2000. What's wrong with a little sex? Journal of Evolutionary Biology, 13: 63-69. DOI: 10.1046/j.14209101.2000.00142.x

PIGLIUCCI, M., C. J. MURREN \& C. D. SCHLICHTING. 2006. Phenotypic plasticity and evolution by genetic assimilation. Journal of Experimental Biology, 209: 2362-2367. DOI: $10.4081 /$ jlimnol.2016.1353

PISCIA, R., N. D. NORMAN \& M. M. MANCA. 2016. Mechanisms underlying recovery of zooplankton in Lake Orta after liming. Journal of Limnology, 75 (2). DOI: 10.4081/jlimnol.2016.1353

POST, D. M. \& E. P. PALKOVACS. 2009. Eco-evolutionary feedbacks in community and ecosystem ecology: interactions between the ecological theatre and the evolutionary play. Philosophical Transactions of the Royal Society B: Biological Sciences, 364 (1523): 1629-1640. DOI: $10.1098 /$ rstb.2009.0012

POURRIOT, R. \& T. W. SNELL. 1983. Resting eggs in rotifers. Hydrobiologia, 104: 213-224. DOI: $10.1007 / \mathrm{BF} 00045970$

RODRÍGUEZ, J. 2016. Ecología. Pirámide, Madrid.

ROSE, M. R. 1991. Evolutionary biology of aging. Oxford University Press.

ROTHHAUPT, K. O. 1990. Differences in particle size-dependent feeding efficiencies of closely related rotifer species. Limnology and Oceanography, 35(1): 16-23. DOI: 10.4319/lo. 
1990.35.1.0016

ROZE, D. 2012. Disentangling the benefits of sex. PLOS Biology, 10(5): e1001321. DOI: 10.1371/journal.pbio.1001321

SCHRÖDER, T., 2005. Diapause in monogonont rotifers. Hydrobiologia 546: 291-306. DOI: 10.1007/s10750-005-4235-x

SERRA, M. \& M. R. MIRACLE. 1987. Biometric variation in three strains of Brachionus plicatilis as a direct response to abiotic variables. Hydrobiologia, 147(1): 83-89. DOI: 10.1007/BF00025729

SERRA, M., A. GÓMEZ \& M. J. CARMONA 1998. Ecological genetics of Brachionus sympatric sibling species. Hydrobiologia, 387/388, 373-384. DOI: 10.1007/978-94-0114782-8 49

SERRA, M., T. W. SNELL \& C. E. KING. 2004. The timing and proportion of sex in monogonont rotifers, In: Evolution: From molecules to ecosystems. A. Moya, \& E. Font (eds.):135-146. Oxford University Press.

SERRA, M. \& T. W. SNELL. 2009. Sex loss in monogonont rotifers. In: Lost sex. I. Schön, K. Martens, \& P. Van Dijk (eds.): 281-294. Berlin, Springer.

SERRA, M., H. A. SMITH, J. S. WEITZ \& T. W. SNELL. 2011. Analysing threshold effects in the sexual dynamics of cyclically parthenogenetic rotifer populations. Hydrobiologia, 662(1): 121-130. DOI: 10.1007/s10750-0100517-z

SERRA, M. \& D. FONTANETO. 2017. Speciation in the Brachionus plicatilis species complex. In: Rotifers. Hagiwara A. \& T. Yoshinaga. (eds.). Fisheries Science Series. Springer, Singapore. DOI: 10.1007/978-98110-5635-2_2

SERRA, M., T. W. SNELL \& R. L. WALLACE. 2018. Reproduction, Overview by Phylogeny: Rotifera. DOI: 10.1016/B978-0-12-8096338.20646-8

SERRANO, L., M. SERRA \& M. R. MIRACLE. 1989. Size variation in Brachionus plicatilis resting eggs. Hydrobiologia, 186: 381-386. DOI: 10.1007/BF00048936

SIELAFF, M., H. SCHMIDT, T. H. STRUCK, D. ROSENKRANZ, D. B. M. WELCH, T. HANKELN \& H. HERLYN. 2016. Phylogeny of
Syndermata (syn. Rotifera): Mitochondrial gene order verifies epizoic Seisonidea as sister to endoparasitic Acanthocephala within monophyletic Hemirotifera. Molecular phylogenetics and evolution. 96: 79-92. DOI: 10.1016/j. ympev.2015.11.017

SIMON J. C., C. RISPE \& P. SUNNUCKS P. 2002. Ecology and evolution of sex in aphids. Trends in Ecology and Evolution, 17: 34-39. DOI: 10.1016/S0169-5347(01)02331-X

SNELL, T. W. 2014. Rotifers as models for the biology of aging. International review of hydrobiology. 99(1-2): 84-95. DOI: 10.1002/ iroh.201301707

SNELL, T. W. \& K. CARRILLO. 1984. Body size variation among strains of the rotifer Brachionus plicatilis. Aquaculture, 37(4): 359-367. DOI: 10.1016/0044-8486(84) 90300-4

SNELL, T. W. \& M. J. CARMONA. 1995. Comparative toxicant sensitivity of sexual and asexual reproduction in the rotifer Brachionus calyciflorus. Environmental Toxicology and Chemistry, 14 (3): 415-420. DOI: 10.1002/etc. 5620140310

SNELL, T. W., R. RICO-MARTÍNEZ, L. N. KELLY, T. E. BATTLE. 1995. Identification of a sex pheromone from a rotifer. Marine Biology 123:347-353. DOI: 10.1007/ BF00353626

SNELL, T. W., B. J. DINGMANN \& M. SERRA. 2001. Density-dependent regulation of natural and laboratory rotifer populations. Hydrobiologia, 446/447: 39-44. DOI: 10.1023/A:1017564804089

SNELL, T. W. \& C-P STELZER. 2005. Removal of surface glycoproteins and transfer among Brachionus species. Hydrobiologia 546: 267-274. DOI: 10.1007/s10750-005-4207-1

SNELL T. \& C. JOAQUIM-JUSTO. 2007. Workshop on rotifers in ecotoxicology. Hydrobiologia 593: 227-232. DOI: 10.1007/ s10750-007-9045-x

SNELL, T. W., T. L. SHEARER, H. A. SMITH, J. KUBANEK, K. E. GRIBBLE, D. B. MARK WELCH. 2009. Genetic determinants of mate recognition in Brachionus manjavacas (Rotifera). BMC Biology 7: 60. DOI: 10.1186/1741-7007-7-60 
SNELL, T. W, A. M. FIELDS \& R. K. JOHNSTON. 2012. Antioxidants can extend lifespan of Brachionus manjavacas (Rotifera), but only in a few combinations. Biogerontology, 13:261-275. DOI: 10.1007/s10522012-9371-X

SNELL, T. W., R. K. JOHNSTON, K. E. GRIBBLE \& D. B. MARK WELCH. 2015. Rotifers as experimental tools for investigating aging. Invertebrate Reproduction and Development, 59: 5-10. DOI: 10.1080/07924259. 2014.925516

STELZER, C. P. 2002. Phenotypic plasticity of body size at different temperatures in a planktonic rotifer: mechanisms and adaptive significance. Functional Ecology, 16: 835-841. DOI: 10.1046/j.1365-2435.2002.00693.x

STELZER, C. P. 2005. Evolution of rotifer life histories. Hydrobiologia, 546, 335-346. DOI: 10.1007/s10750-005-4243-x

STELZER, C. P. 2011a. The cost of sex and competition between cyclical and obligate parthenogenetic rotifers. American Naturalist, 177: 43-53. DOI: $10.1086 / 657685$

STELZER, C. P. 2011b. A first assessment of genome size diversity in Monogonont rotifers. Hydrobiologia, 662(1), 77-82. DOI: 10.1007/ s10750-010-0487-1

STELZER, C. P. 2015. Does the avoidance of sexual costs increase fitness in asexual invaders? Proceedings of the National Academy of Sciences of the United States of America, 112: 8851-8858. DOI: 10.1073/ pnas. 1501726112

STELZER, C. P. 2017. Extremely short diapause in rotifers and its fitness consequences. Hydrobiologia, 796(1), 255-264. DOI: 10.1007/s10750-016-2937-x

STELZER, C. P. \& T. W. SNELL. 2003. Induction of sexual reproduction in Brachionus plicatilis (Monogononta, Rotifera) by a density-dependent chemical cue. Limnology \& Oceanography, 48: 939-943. DOI: 10.4319/ 1o.2003.48.2.0939

STELZER, C. P. \& J. LEHTONEN. 2017. Diapause and maintenance of facultative sexual reproductive strategies. Philosophical Transactions of the Royal Society B-Biological Sciences, 371: 20150536. DOI: 10.1098/rstb. 2015.0536

SUATONI E., S. VICARIO, S. RICE, T. W. SNELL \& A. CACCONE. 2006. An analysis of species boundaries and biogeographic patterns in a cryptic species complex: the rotifer Brachionus plicatilis. Molecular Phylogenetics and Evolution 41: 86-98. DOI: 10.1016/j.ympev.2006.04.025

SUN, D. \& C. NIU. 2012. Adaptive significance of temperature-induced egg size plasticity in a planktonic rotifer, Brachionus calyciflorus. Journal of Plankton Research, 34: 864-873. DOI: $10.1093 /$ plankt/fbs050

TARAZONA E., E. M. GARCÍA-ROGER \& M. J. CARMONA. 2017. Experimental evolution of bet hedging in rotifer diapause traits as a response to environmental unpredictability. Oikos, 126(8): 1162-1172. DOI: 10.1111/oik.04186

TEMPRANO, M., I. MORENO, M. J. CARMONA \& M. SERRA, 1994. Size and age at maturity of two strains of the rotifer Brachionus plicatilis in relation to food level. Internationale Vereinigung für theoretische und angewandte Limnologie: Verhandlungen, 25 (4): 2327-2331.

TORTAJADA, A. M., M. J. CARMONA \& M. SERRA. 2009. Does haplodiploidy purge inbreeding depression in rotifer populations? PLOS ONE, 4(12): e8195. DOI: 10.1371/ journal.pone.0008195

TORTAJADA, A. M., M. J. CARMONA \& M. SERRA. 2010. Effects of population outcrossing on rotifer fitness. BMC Evolutionary Biology, 10: 312-324. DOI: 10.1186/1471-2148-10-312

TSCHUGUNOFF, N. L., 1921. Über das Plankton des nördlichen Teiles des Kaspisees. Raboty Volzhskoj Biologicheskoj Stancii, Saratov 6: 159-162

TURCHIN, P. 2001. Does population ecology have general laws? Oikos, 94 (1): 17-26. DOI: 10.1034/j.1600-0706.2001.11310.x

VAN DER STAP, I., M. VOS \& W. M. MOOIJ. 2007. Inducible defenses and rotifer food chain dynamics. Hydrobiologia 593:103-110. DOI: $10.1007 / \mathrm{s} 10750-007-9051-\mathrm{Z}$

WALCZYNSKA, A. \& M. SERRA. 2014 a. Inter- and intraspecific relationships between 
performance and temperature in a cryptic species complex of the rotifer Brachionus plicatilis. Hydrobiologia, 734: 17-26. DOI: 10.1007/s10750-014-1859-8

WALCZYNSKA, A. \& M. SERRA. $2014 \mathrm{~b}$. Species size affects hatching response to different temperature regimes in a cryptic species complex. Evolutionary Ecology 28: 131-140. DOI: 10.1007/s10682-013-9664-9

WALCZYNSKA, A., L. FRANCH-GRAS \& M. SERRA. 2017. Empirical evidence for fast temperature-dependent body size evolution in rotifers. Hydrobiologia, DOI: 10.1007/s10750017-3206-3

WALLACE, R. L., T. W. SNELL, \& H. A. SMITH. 2015. Rotifer: ecology and general biology. In: Freshwater Invertebrates, Vol. I, Chap 13. J. Thorp \& A. Covich (eds). Elsevier, London

WALSH, E. J., T. SCHRÖDER, R. L. WALLACE \& R. RICO-MARTINEZ. 2009. Speciation in Lecane bulla (Monogononta: Rotifera) in Chihuahuan Desert waters. Verhandlungen des Internationalen Verein Limnologie, 30: 1046-1050. DOI: 10.1080/03680770. 2009.11902298

WALZ, N. 1983. Continuous culture of the pelagic rotifers Keratella cochlearis and Brachionus angularis. Archiv für Hydrobiologie, 98: 70-92.
WALZ, N. 1987. Comparative population dynamics of the rotifers Brachionus angularis and Keratella cochlearis. Hydrobiologia, 147:209-213. DOI: 10.1007/BF00025744

WALZ, N. (Ed.). 2012. Plankton regulation dynamics: experiments and models in rotifer continuous cultures (Vol. 98). Springer Science \& Business Media.

WILlIAMS, G. C. 1975. Sex and Evolution. Princeton Univ. Press, Princeton, NJ.

YIN, X. W., N. X. ZHAO, B. H. WANG, W. J. LI \& Z. N. ZHANG. 2015. Transgenerational and within-generational induction of defensive morphology in Brachionus calyciflorus (Rotifera): importance of maternal effect. Hydrobiologia, $\quad 742, \quad 313-325 . \quad$ DOI: 10.1007/s10750-014-1995-1

ZIV, T., V. CHALIFA-CASPI, N. DENEKAMP, I. PLASCHKES, S. KIERSZNIOWSKA, I. BLAIS, A. ADMON \& E. LUBZENS. 2017. Dormancy in embryos: insight from hydrated encysted embryos of an aquatic invertebrate. Molecular and Cellular Proteomics, 16(10): 1746-1769. DOI: 10.1074/mcp.RA117.000109

ZWEERUS, N. L., S. SOMMER, D. FONTANETO \& A. OZGUL. 2017. Life-history responses to environmental change revealed by resurrected rotifers from a historically polluted lake. Hydrobiologia, 796(1): 121-130. DOI: 10.1007/s10750-016-3070-6

Con el apoyo de:
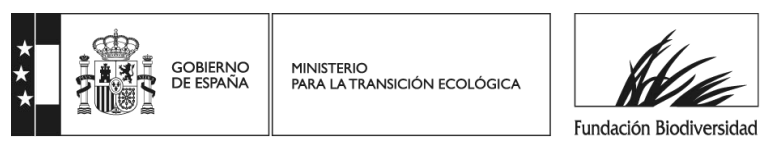